\title{
Detection of low bottom water oxygen concentrations in the North Sea; implications for monitoring and assessment of ecosystem health
}

\author{
N. Greenwood ${ }^{1}$, E. R. Parker ${ }^{1}$, L. Fernand ${ }^{1}$, D. B. Sivyer ${ }^{1}$, K. Weston ${ }^{2}$, S. J. Painting ${ }^{1}$, S. Kröger ${ }^{1}$, R. M. Forster ${ }^{1}$, \\ H. E. Lees ${ }^{1}$, D. K. Mills ${ }^{1}$, and R. W. P. M. Laane ${ }^{3}$ \\ ${ }^{1}$ Centre for Environment, Fisheries and Aquaculture Science (Cefas), Lowestoft, Suffolk, NR33 0HT, UK \\ ${ }^{2}$ Laboratory of Global Marine and Atmospheric Chemistry, School of Environmental Sciences, University of East Anglia, \\ NR7 4TJ, UK \\ ${ }^{3}$ Deltares, P. O. Box 177, 2600 MH Delft, The Netherlands
}

Received: 31 July 2009 - Published in Biogeosciences Discuss.: 26 August 2009

Revised: 24 February 2010 - Accepted: 3 March 2010 - Published: 29 April 2010

\begin{abstract}
This paper presents new results from high temporal resolution observations over two years (2007 and 2008) from instrumented moorings deployed in the central North Sea, at the Oyster Grounds and on the northern slope of Dogger Bank (North Dogger). The water column was stratified in the summer at both sites, leading to limited exchange of the water in the bottom mixed layer. Data from these moorings revealed the variable nature of summer oxygen depletion at the Oyster Grounds. The combination of in situ and ship-based measurements allowed the physical and biological conditions leading to decreasing dissolved oxygen concentrations in bottom water to be examined. In 2007 and 2008, the concentration of dissolved oxygen in the bottom water at both sites was observed to decrease throughout the summer period after the onset of stratification. Depleted dissolved oxygen concentration $\left(6.5 \mathrm{mg} \mathrm{l}^{-1}, 71 \%\right.$ saturation) was measured at the North Dogger, a site which is not significantly influenced by anthropogenic nutrient inputs. Lower oxygen saturation $\left(5.2 \mathrm{mg} \mathrm{l}^{-1}, 60 \%\right.$ saturation) was measured for short durations at the Oyster Grounds. The seasonal increase in bottom water temperature accounted for $55 \%$ of the decrease in dissolved oxygen concentration at the Oyster Grounds compared to $10 \%$ at North Dogger.

Dissolved oxygen concentration in bottom water at the Oyster Grounds was shown to be strongly influenced by short term events including storms and pulses of particulate organic matter input. In contrast, dissolved oxygen concentration in bottom water at the North Dogger reflected longer sea-
\end{abstract}

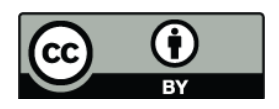

Correspondence to: N. Greenwood (naomi.greenwood@cefas.co.uk) sonal processes such as a gradual temperature increase over the summer and a more steady supply of particulate organic matter to the bottom mixed layer. The differences between the study sites shows the need for an improved understanding of the mechanisms driving these processes if the use of oxygen in marine management and ensuring ecosystem health is to be meaningful and successful in the future. These high frequency observations provide greater understanding of the nature of the depletion in bottom oxygen concentration in the North Sea.

\section{Introduction}

Coastal seas are highly productive environments under considerable stress from human activities and respond to these stresses in diverse ways reflecting their biogeochemistry and physical structure (Jickells, 1998). Dissolved oxygen levels in parts of the marine environment have shown rapid change since the 1950s, especially in regions which have been adversely affected by anthropogenic forcing (Diaz, 2001). Undersaturation of oxygen in a water mass occurs when the rate of aerobic decomposition of organic carbon by microbial respiration is greater than the rate of re-supply of oxygen (Rabalais et al., 2010). Organic material is primarily generated through photosynthesis of algae which can be increased by anthropogenic enrichment of nutrients. In the coastal zone, inputs of sewage discharge may additionally increase the organic loading of a water mass. Oxygen depletion may occur over a variety of timescales, defined by Kemp et al. (2009) as (1) permanent, (2) persistent seasonal, both stratified and vertically mixed, (3) episodic and (4) diel. Factors which

Published by Copernicus Publications on behalf of the European Geosciences Union. 
influence the nature and severity of oxygen depletion include external forcing of physical and biological processes and internal ecological processes which regulate biogeochemical fluxes (Kemp et al., 2009).

Anthropogenic pressures on water bodies may create new areas of oxygen depletion or exacerbate areas which have a natural tendency for low oxygen concentrations. For example, increased dissolved nutrient inputs have resulted in an anthropogenically induced region of dissolved oxygen below $2 \mathrm{ml}^{-1}\left(2.9 \mathrm{mg} \mathrm{l}^{-1}\right)$ in large areas $\left(70000 \mathrm{~km}^{2}\right)$ of the Baltic Sea (Conley et al., 2002). Large quantities of nutrients have been discharged into the Black Sea with $90 \%$ of its volume classified as anoxic (Mee, 1992) and new areas of hypoxia are being observed globally (Chan et al., 2008). Hypoxia (dissolved oxygen concentration below $2 \mathrm{mgl}^{-1}$ ) and less severely depleted dissolved oxygen concentrations have the potential to cause lethal and sub-lethal effects to a range of benthic organisms (Cheung et al., 2008; Long et al., 2008; Vaquer-Sunyer and Duarte, 2008; Levin et al., 2009) and fish (Chabot and Claireaux, 2008; Hassell et al., 2008; Skjæraasen et al., 2008; Wang et al., 2008; Ekau et al., 2009) which may cause loss of biodiversity in these impacted ecosystems (Breitburg et al., 2009). Increasing eutrophication-induced hypoxia has led to dead zones affecting more than $245000 \mathrm{~km}^{2}$ of marine ecosystems worldwide (Diaz and Rosenberg, 2008).

Oxygen minimum zones (OMZ) typically exhibit permanent oxygen deficiency and may be considered as areas where oxygen depletion occurs naturally to levels considered hypoxic or even anoxic. This may be due to extended water residence time, restricted exchange and ventilation of water, stratification or high export of carbon to the bottom layer (Rabalais et al., 2010). Examples of OMZ include silled basins and fjords such as Saanich Inlet, British Columbia, Canada (Tunnicliffe, 1981) with oxygen concentrations of less than $1.0 \mathrm{ml}^{-1}\left(1.4 \mathrm{mgl}^{-1}\right)$ and upwelling systems within the Pacific and South and North Atlantic Oceans where oxygen concentrations may reach below $1 \mu \mathrm{mol} \mathrm{kg}{ }^{-1}$ (approximately $0.1 \mathrm{mg} \mathrm{l}^{-1}$ ), $17 \mu \mathrm{mol} \mathrm{kg} \mathrm{kg}^{-1}$ (approximately $0.6 \mathrm{mgl}^{-1}$ ) and more than $40 \mu \mathrm{mol} \mathrm{kg}-1$ (approximately $1.3 \mathrm{mgl}^{-1}$ ) respectively (Karstensen et al., 2008). Ventilation of bottom water through horizontal and vertical advection has been shown to be important in controlling oxygen concentrations in the Baltic Sea (Conley et al., 2002; Bendtsen et al., 2009) where variations in saltwater inflows from the North Sea strongly influence bottom water dissolved oxygen concentrations.

In vertically stratified systems, oxygen production occurs in the surface layer and consumption occurs in the bottom layer (Weston et al., 2008). In such systems, the oxygen concentration in the bottom water is typically determined by oxygen respiration and ventilation which have opposing effects on dissolved oxygen concentration (Kemp et al., 2009). Seasonal oxygen depletion is characteristic of such stratified systems and is the focus of this paper.
The offshore regions of the North Sea have had few published studies on bottom water oxygen concentrations, with most focussing on coastal waters such as the German Bight (Colijn et al., 2002). Earlier studies have shown the potential for low oxygen events in the central North Sea (Postma and Rommets, 1984; Peeters et al., 1995; Boers, 2005; Weston et al., 2008; De Wilde et al., 1984) but seasonal and temporal coverage was limited. The North Sea, being surrounded by the industrialised nations of northern Europe including the United Kingdom, The Netherlands, Belgium, Denmark and Germany, receives significant anthropogenic nutrient riverine input with the Rhine, for example, resulting in dissolved inorganic nitrogen inputs of $\sim 300$ ktonnes $^{-1}$ (De Jonge et al., 1996). The semi-enclosed nature of the North Sea also leads to residence times in the order of weeks in southern and central regions (Weston et al., 2004) and therefore, in combination with water column stratification, leads to the isolation of bottom water. There is therefore the potential in certain areas of this shelf sea for high primary production (Joint and Pomroy, 1993). This production will sink into the bottom layer and will be remineralised which may lead to low bottom water oxygen concentration when bottom waters are isolated from air-sea exchange due to stratification.

Current climate change scenarios for the North Sea show an earlier onset and increased magnitude of stratification (Lowe et al., 2009). A longer period of stratification will increase the length of time bottom waters are isolated from oxygen-rich surface water and may therefore lead to even lower bottom water oxygen concentrations. In addition, future changes in climatic conditions may be important in controlling nutrient fluxes from rivers into the coastal environment (Justić et al., 2003) with increases in extreme events leading to increases in nutrient fluxes. This may increase the susceptibility of coastal and shallow offshore environments to eutrophication and consequent low oxygen and hypoxic events. An understanding of the complex interplay of the factors which control oxygen levels is therefore necessary to effectively manage these areas. Knowing the natural variability both temporally and spatially is essential to understanding the process of hypoxia development and assessing the extent of anthropogenic influence.

Oxygen is a fundamental biogeochemical component and it is used as a key supporting element in assessing the ecological status of marine and estuarine environments (Best et al., 2007). The concentration of dissolved oxygen is regarded as an important indicator of ecosystem health and plays a role in the assessment of good ecological status as required by the EU's Water Framework Directive (Best et al., 2007). An Ecological Quality Framework is central to the ecosystembased approach for the management of the North Sea (Heslenfeld and Enserink, 2008; Johnson, 2008) and the use of oxygen as an Ecological Quality Objective within this framework has been established (Painting et al., 2005; Devlin et al., 2007; Heslenfeld and Enserink, 2008). Oxygen is also one of the indicators used in the OSPAR Common Procedure 
(OSPAR, 2005) used for assessment of eutrophication and may be an indicator of "Good Environmental Status" (GES) as required by the European Marine Strategy Framework Directive (EU, 2008). Consequently, understanding the causes of any observed low oxygen concentrations is critical to an accurate diagnosis of cause (e.g. increased anthropogenic nutrient inputs) and subsequent responses by responsible authorities required to reduce or eliminate anthropogenic eutrophication.

The assessment of dissolved oxygen concentration has been used historically within several regulatory frameworks (Best et al., 2007) with various thresholds applied. For the purposes of this paper, low oxygen concentration is defined as $<4 \mathrm{mgl}^{-1}$. This is the threshold used by England and Wales in the OSPAR eutrophication assessment of their marine waters (Foden et al., 2010) and is based on the UK classification scheme to be used within the Water Framework Directive (Best et al., 2007). However, a dissolved oxygen concentration of between $2 \mathrm{mgl}^{-1}$ and $6 \mathrm{mgl}^{-1}$ has been considered by some to be oxygen deficient (OSPAR, 2005).

The aim of this work was to investigate dissolved oxygen concentrations in bottom water at two sites in the North Sea and advance our understanding of how the dissolved oxygen concentration in different regions of this important shelf sea responds to varying water column structure. This was achieved using a combination of instrumented moorings at two sites to provide high temporal resolution measurements and ship based CTD measurements.

\section{Methods}

\subsection{Study area}

The North Sea is part of the wider northwest European shelf; it is a semi-enclosed basin with a general anti-clockwise circulation, primarily open to the Atlantic in the north (Hill, 1973). It has a total area of $575000 \mathrm{~km}^{2}$ with the majority of the southern North Sea being relatively shallow $(\sim 40 \mathrm{~m})$ and well-mixed year round due to its shallow depth and strong tidal currents opposing summer stratification (Howarth et al., 1993). The northern and central regions stratify throughout summer (Pingree et al., 1978) with only the deepest parts (>80 m depth) of the northern North Sea remaining stratified at the end of the autumn (Hill, 1973). The majority of the water mass in this region is due to Atlantic input from the north, although there are other marine inputs through the English Channel and significant low salinity input from the Baltic via the Skaggerak (Hill, 1973). The spring bloom in the offshore regions of the North Sea typically occurs in March/early April, depleting nutrients in the surface water and supplying particulate organic matter to the bottom mixed layer (BML). After the die back of the spring bloom, deep chlorophyll maxima (DCM) form extensively in the summer stratified regions of the North Sea, fuelled by new inputs of nutrients into the thermocline (Richardson et al., 2000; Weston et al., 2008) and they are a potential source of biomass to bottom waters throughout the stratified period. Production associated with the DCM has been estimated to account for $37 \%$ of annual new production in the summer stratified North Sea (Weston et al., 2005) so its input to the bottom mixed layer may be important in summer.

Detailed observations of temperature, salinity and oxygen dynamics were carried out using instrumented moorings at two stations located in the summer-stratified region of the central North Sea (Fig. 1). The two study sites, Oyster Grounds and north of the Dogger Bank (referred to as North Dogger), were sampled on nine cruises between February 2007 and September 2008. The observations carried out at the Oyster Grounds form part of a eutrophication monitoring programme using an operational SmartBuoy network (Mills et al., 2003).

\subsubsection{North Dogger}

The mooring was located at $55^{\circ} 41.00^{\prime} \mathrm{N}, 02^{\circ} 16.80^{\prime} \mathrm{E}$, on the north slope of the Dogger Bank. Dogger Bank is a $300 \mathrm{~km}$ long sand bank, shallow $(\sim 20 \mathrm{~m})$ and is shown outlined by the central $40 \mathrm{~m}$ contour (Fig. 1). Although the water column on top of Dogger Bank is well-mixed year-round, the mooring was situated in an area which exhibits thermal stratification north of the frontal region (Pedersen, 1994) in a 85 $\mathrm{m}$ water column depth. This water north of Dogger Bank is influenced predominantly by Atlantic water inflow through the Orkney - Shetland gap (Pedersen, 1994). While this site is only a short distance from a significant transport pathway resulting from seasonal baroclinic flow from the north east coast of England (Brown et al., 1999), the predominant source of nutrients is of Atlantic origin. Low oxygen concentrations near the bottom were reported in 1916 by Gehrke (in Postma and Rommets, 1984) although a limited data set is available. After the occurrence of the spring bloom, a DCM is a feature of this site during summer (Richardson et al., 2000; Weston et al., 2005).

\subsubsection{Oyster Grounds}

The Oyster Grounds, or Oyster Ground, is a large, circular depression in the central North Sea centred at $54^{\circ} 30^{\prime} \mathrm{N}$ and $4^{\circ} 30^{\prime} \mathrm{E}$ (Fig. 1). It reaches a maximum depth of $\sim 50 \mathrm{~m}$ at its centre and is bordered by the shallower bathymetry of Dogger Bank, German Bight and Southern Bight. Bottom fronts prevent water mass transfer along the seabed into the Oyster Grounds (Weston et al., 2008) isolating a shallow BML during summer and low bottom water oxygen concentrations have been reported in previous studies (Postma and Rommets, 1984; Peeters et al., 1995; Boers, 2005; Weston et al., 2008). Previous studies have also shown the presence of a DCM at this site during summer (Weston et al., 2008). The 


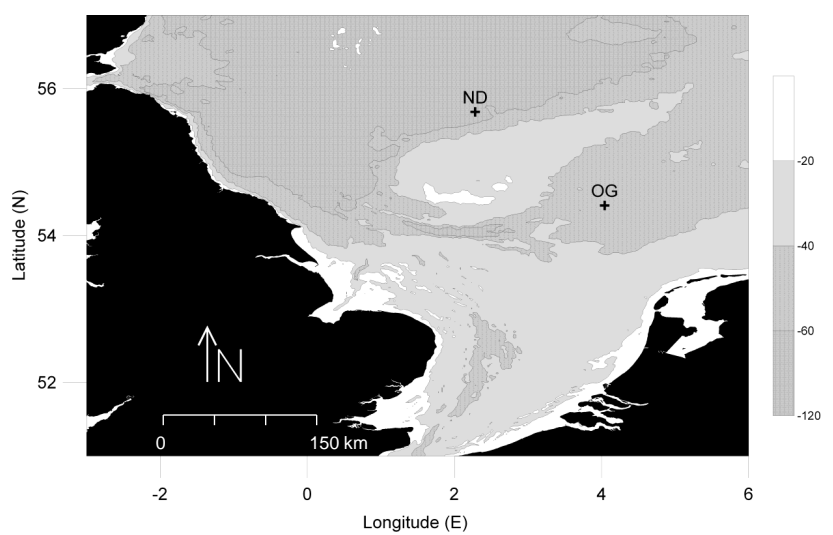

Fig. 1. Location of study sites in the North Sea. OG is Oyster Grounds, ND is North Dogger.

mooring was located at $54^{\circ} 24.84^{\prime} \mathrm{N}, 04^{\circ} 02.50^{\prime} \mathrm{E}$ in a water column depth of $45 \mathrm{~m}$.

\subsection{Discrete sample collection and analysis}

Water samples for discrete measurements were collected at selected depths using a CTD rosette of 10 litre Niskin bottles when visiting the moorings for servicing. The CTD rosette was fitted with an FSI Integrated CTD (Falmouth Scientific Inc., USA) to provide salinity, temperature and depth data and for data acquisition. For chlorophyll measurements, known volumes were filtered through glass fibre filters (GF/F; Whatman, UK) in triplicate. Pigments were immediately extracted in $90 \%$ buffered acetone and refrigerated prior to analysis. A Turner Designs Model 10AU filter fluorometer (USA) was used to measure the fluorescence of extracted chlorophyll and phaeopigment before and after acidification following the method described by Tett (1987). The fluorometer was calibrated using a solution of pure chlorophyll $a$ (Sigma-Aldrich, USA) with concentration being determined spectrophotometrically. The error of chlorophyll analyses was $<2 \%$ relative to Turner certified reference material.

Water samples for oxygen determination were collected and preserved in triplicate using the Winkler method (Winkler, 1888). Samples were analysed on board using an automatic titration system (Sensoren Instrumente Systeme, Germany) with a photometric endpoint according to Williams and Jenkinson (1982). For measurements of suspended particulate matter (SPM), known volumes were passed through pre-weighed $0.4 \mu \mathrm{m}$ polycarbonate filters and rinsed with $2 \times 50 \mathrm{ml}$ ultrapure water. Filters were then dried in a desiccator at room temperature and weighed until filter weight remained constant. Samples were analysed for salinity using a Guildline 8400B salinometer (Canada) which had been standardised with IAPSO standard seawater.
Quality control of results for discrete samples analysed for salinity and chlorophyll was assured by participation in the Quality Assurance for Marine Environmental Measurements (QUASIMEME) scheme.

\subsection{Moored instrumentation}

In situ, high frequency measurements were made at the surface, mid water and on seabed landers at both Oyster Grounds and North Dogger. Conductivity, temperature, chlorophyll fluorescence and optical backscatter were measured at $1 \mathrm{~m}, 35 \mathrm{~m}$ and $45 \mathrm{~m}$ (seabed lander) at the Oyster Grounds and at $1 \mathrm{~m}, 31 \mathrm{~m}$ and $85 \mathrm{~m}$ (seabed lander) at North Dogger. In addition, dissolved oxygen concentration and percent saturation were measured at $35 \mathrm{~m}$ and $45 \mathrm{~m}$ at the Oyster Grounds and at $31 \mathrm{~m}$ and $85 \mathrm{~m}$ at North Dogger. Measurements at $1 \mathrm{~m}$ and $31 \mathrm{~m}$ at the Oyster Grounds started in March 2006 and data from 1 January 2007 are presented in this paper. Measurements at $45 \mathrm{~m}$ started on 21 April 2007. Measurements at all depths at North Dogger started on 24 February 2007.

A solid state data logger (ESM-2) designed and built by Centre for Environment, Fisheries and Aquaculture Science (Cefas, UK) was used for data acquisition and sensor control. Chlorophyll fluorescence was measured using a Seapoint chlorophyll fluorometer and turbidity with a Seapoint turbidity meter (Seapoint Inc., USA). Measurements of conductivity and temperature were made using either an FSI CT sensor (Falmouth Scientific Inc., USA) or an Aanderaa conductivity sensor (AADI, Norway). Oxygen concentrations were determined using an Aanderaa optode (AADI, Norway). Measurements were recorded at a frequency of $1 \mathrm{~Hz}$ for turbidity, chlorophyll fluorescence and temperature and conductivity from FSI sensors and at $5 \mathrm{~Hz}$ for Aanderaa optode and Aanderaa conductivity sensors, with a burst frequency of 2 per hour and a burst duration of between 5 and 10 min depending on the length of mooring deployment.

Instruments on the moorings at North Dogger and Oyster Grounds seabed lander were exchanged with serviced instruments when each site was visited during the research programme. Instruments on the moorings at Oyster Grounds surface and mid-water were exchanged with serviced instruments within the routine monitoring programme conducted by Directorate Noordzee (DNZ) during surveys carried out as part of the Netherlands national marine monitoring programme. Data from the moorings were passed through a defined quality assurance protocol and only data which passed the protocol is presented here. Daily average data were calculated from all burst average data which passed the QA protocol. Breaks in data are due to instrumentation failure or biofouling of sensors which is a common problem in these productive regions (Manov et al., 2004). Chlorophyll fluorometers were calibrated using results from discrete samples collected and analysed as described above $\left(n=119, r^{2}=0.74\right.$, $P>0.01)$. Optical backscatter sensors were calibrated for 
SPM using results from discrete samples collected and analysed as above $\left(n=45, r^{2}=0.89, P>0.01\right)$. Results of discrete oxygen samples were used to calibrate data from the optodes.

An Acoustic Doppler Current Profiler with a frequency of $300 \mathrm{kHz}$ or $600 \mathrm{kHz}$ (Teledyne RDI, USA or Nortek AS, Norway) was deployed on each lander. The instrument was configured to record a sample of 120 pings every $10 \mathrm{~min}$ with a bin size of $1 \mathrm{~m}$ and $2 \mathrm{~m}$ for $600 \mathrm{kHz}$ and $300 \mathrm{kHz}$ instruments respectively. Wave height data was obtained from the Anasuria platform (WMO ID 62164) located at $57^{\circ} 15^{\prime} 38 \mathrm{~N}, 000^{\circ} 48^{\prime} 48 \mathrm{E}$ (obtained from http://www.cefas. co.uk/data/wavenet.aspx) and a daily average wave height was calculated.

\section{Results}

\subsection{CTD surveys}

CTD results (Table 1) showed that the water column at both sites was well mixed when sampled during the winter (February 2007, January 2008). Both sites were thermally stratified by April and the maximum temperature difference between surface and bottom water was $3.6^{\circ} \mathrm{C}$ at Oyster Grounds (August 2008) and $8.2^{\circ} \mathrm{C}$ at North Dogger (September 2008). The Oyster Grounds had returned to being well mixed again when sampled in September 2007 whereas North Dogger remained stratified at the beginning of November. In 2008, both sites were still stratified on the last sampling visit (August for the Oyster Grounds and September for North Dogger). The height of the bottom mixed layer (BML) varied with the time of year, varying between $20 \mathrm{~m}$ and $30 \mathrm{~m}$ above the seabed at Oyster Grounds and $26 \mathrm{~m}$ to $50 \mathrm{~m}$ above the seabed at North Dogger (Table 1). A DCM was observed at Oyster Grounds in May 2007 and August 2008 and at North Dogger in May 2007 and April and September 2008 from CTD casts (results not shown).

\subsection{Oyster Ground in situ monitoring}

Temperatures ranged between $6.1^{\circ} \mathrm{C}$ (March 2008) and $17.7^{\circ} \mathrm{C}$ (surface water, July 2008). The water column was well mixed during autumn and winter but began to stratify (where the start of stratification is defined as when there is $1{ }^{\circ} \mathrm{C}$ difference between surface and bottom) from 7 April 2007 (Fig. 2a). The onset of stratification in 2008 occurred on 26 April 2008, later than for 2007. However, the surface temperature increased more rapidly in 2008 compared to 2007 and the maximum temperature difference between the surface and $45 \mathrm{~m}$ was $8.7^{\circ} \mathrm{C}$ on 9 June 2008 compared to $6.8^{\circ} \mathrm{C}$ on 23 June 2007 . During the monitoring period, the temperature difference between $35 \mathrm{~m}$ and $45 \mathrm{~m}$ was generally less than $0.1{ }^{\circ} \mathrm{C}$, therefore measurements made at $35 \mathrm{~m}$ are assumed to be representative of the conditions at $45 \mathrm{~m}$.
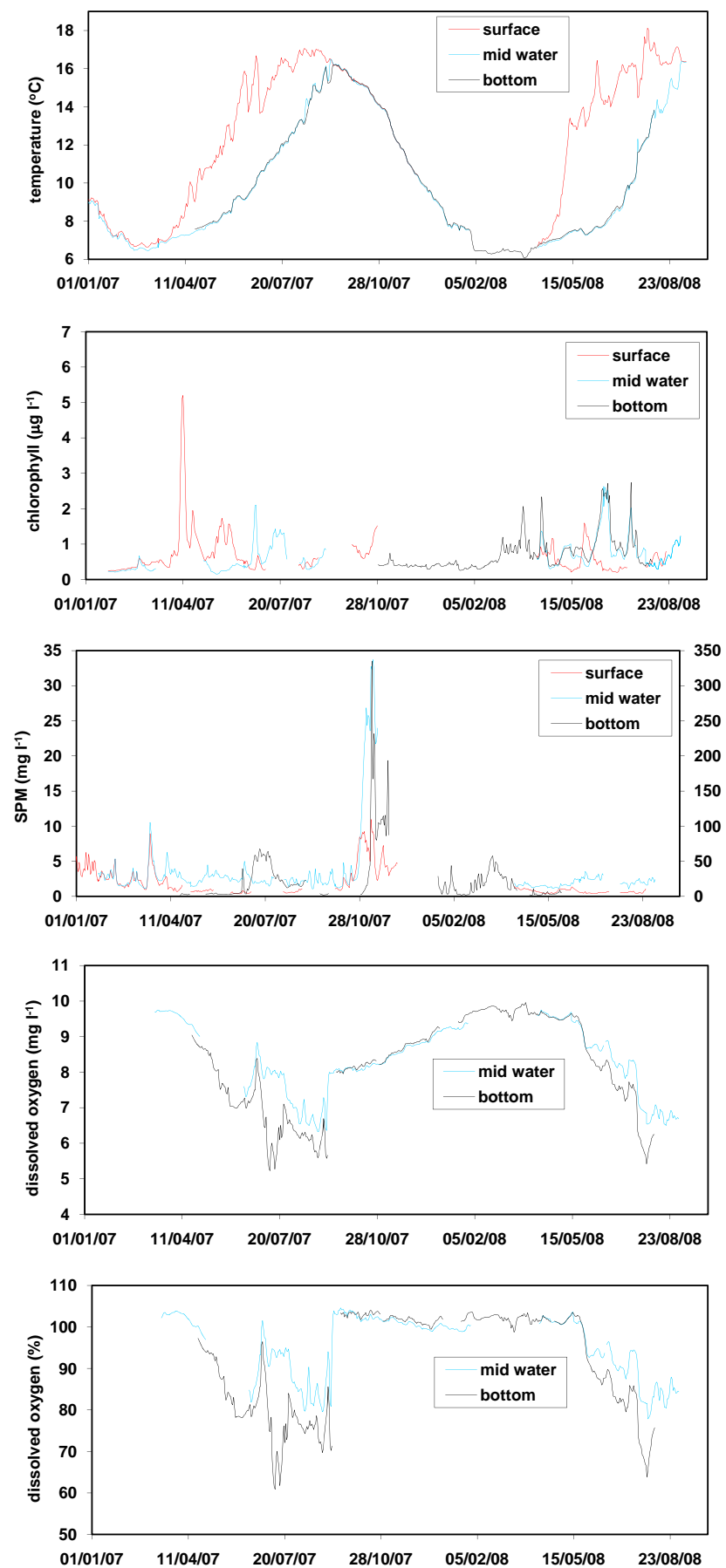

Fig. 2. Mooring data from Oyster Grounds for (a) temperature, (b) chlorophyll, (c) SPM (surface and mid-water on primary y axis, bottom on secondary y axis), (d) oxygen concentration and (e) oxygen percent saturation.

Winter chlorophyll concentrations (November to March) were between $0.2 \mu \mathrm{g} \mathrm{l}^{-1}$ and $0.5 \mu \mathrm{g} \mathrm{l}^{-1}$ at all sampling depths (Fig. 2b). There was a phytoplankton bloom (defined as greater than the winter concentration of $0.5 \mu \mathrm{g}^{-1}$ ) at the surface between 6 and 19 April 2007 with a peak of $5.1 \mu \mathrm{g} \mathrm{l^{-1 }}$ 
Table 1. Summary of CTD data, averaged for all CTD casts at each site on each cruise. SML is surface mixed layer, BML is bottom mixed layer, $\Delta T$ is temperature difference between SML and BML, $\delta T$ is the rate of change of temperature across the thermocline.

\begin{tabular}{|c|c|c|c|c|c|c|c|}
\hline Location & $\begin{array}{l}\text { Dates of } \\
\text { CTD casts }\end{array}$ & $\begin{array}{c}\text { SML } \\
\text { temperature } \\
\left({ }^{\circ} \mathrm{C}\right)\end{array}$ & $\begin{array}{c}\text { BML } \\
\text { temperature } \\
\left({ }^{\circ} \mathrm{C}\right)\end{array}$ & $\begin{array}{l}\Delta T \\
\left({ }^{\circ} \mathrm{C}\right)\end{array}$ & $\begin{array}{l}\text { Depth of } \\
\text { thermocline } \\
\text { (m) }\end{array}$ & $\begin{array}{c}\delta T \\
\left({ }^{\circ} \mathrm{C} \mathrm{m}^{-1}\right)\end{array}$ & $\begin{array}{c}\text { Height } \\
\text { of BML }(\mathrm{m})\end{array}$ \\
\hline \multirow[t]{8}{*}{ Oyster Grounds } & Feb 2007 & 6.9 & 6.9 & 0 & - & - & - \\
\hline & Apr 2007 & 9.0 & 7.5 & 1.5 & $21-25$ & 0.4 & $20-24$ \\
\hline & May 2007 & 11.7 & 8.2 & 3.5 & $15-22$ & 0.5 & $23-30$ \\
\hline & Sep 2007 & 16.1 & 16.1 & 0 & - & - & - \\
\hline & Oct 2007 & 14.0 & 14.0 & 0 & - & - & - \\
\hline & Jan 2008 & 7.4 & 7.4 & 0 & - & - & - \\
\hline & Apr 2008 & 7.8 & 7.0 & 0.8 & $12-20$ & 0.1 & 25 \\
\hline & Aug 2008 & 17.3 & 13.7 & 3.6 & $14-17$ & 1.2 & 28 \\
\hline \multirow[t]{9}{*}{ North Dogger } & Feb 2007 & 7.7 & 7.7 & 0 & - & - & - \\
\hline & Apr 2007 & 8.8 & 7.6 & 2.2 & $37-47$ & 0.2 & $38-48$ \\
\hline & May 2007 & 11.0 & 10.0 & 1.0 & $1-10$ & 0.1 & $50-37$ \\
\hline & (double thermocline) & 10.0 & 7.6 & 2.4 & $35-48$ & 0.2 & \\
\hline & Sep 2007 & 14.3 & 8.3 & 6.0 & $45-51$ & 1.0 & $34-40$ \\
\hline & Oct 2007 & 12.3 & 8.5 & 3.8 & $54-59$ & 0.8 & $26-31$ \\
\hline & Jan 2008 & 7.9 & 7.9 & 0 & - & - & - \\
\hline & Apr 2008 & 8.2 & 6.9 & 1.3 & $20-35$ & 0.1 & 50 \\
\hline & Sep 2008 & 15.6 & 7.4 & 8.2 & $24-36$ & 0.7 & 49 \\
\hline
\end{tabular}

and a second bloom between 14 May and 7 June 2007 with a peak of $1.7 \mu \mathrm{g}^{-1}$. There was a bloom at $35 \mathrm{~m}$ between 20 June and 1 July 2007, with a peak of $2.0 \mu \mathrm{g} 1^{-1}$ and another bloom between 6 and 27 July 2007, with a peak of $1.4 \mu \mathrm{g} 1^{-1}$. There was a series of peaks in chlorophyll concentration at the seabed up to $2.6 \mu \mathrm{g} 1^{-1}$ starting on 2 March 2008 which continued until the observations ceased at the start of September 2008.

The concentration of SPM was generally low at the surface and at $35 \mathrm{~m}$, typically between $1 \mathrm{mg}^{-1}$ and $6 \mathrm{mg} \mathrm{l}^{-1}$ (Fig. 2c). A peak of $10 \mathrm{mgl}^{-1}$ was recorded at the surface and mid-water at the end of March 2007 and peaks in SPM concentration above the seabed of $40 \mathrm{mgl}^{-1}$ and $66 \mathrm{mg} \mathrm{l}^{-1}$ were observed on the 26 June, and between 3 July to $13 \mathrm{Au}-$ gust, respectively. SPM concentration increased throughout the water column from 25 October, with maximum concentrations of $11 \mathrm{mg} \mathrm{l}^{-1}, 34 \mathrm{mg} \mathrm{l}^{-1}$ and $232 \mathrm{mg} \mathrm{l}^{-1}$ observed at the surface, $35 \mathrm{~m}$ and the seabed respectively between 9 and 12 November. SPM concentration remained elevated close to the seabed and at $35 \mathrm{~m}$ after this but decreased to below $5 \mathrm{mgl}^{-1}$ at the surface. There were several peaks in SPM concentration at the seabed during winter 2007/08, with a maximum of $58 \mathrm{mg} \mathrm{l}^{-1}$ on 17 March 2008. SPM concentration above the seabed decreased to less than $5 \mathrm{mgl}^{-1}$ at the end of March 2008 and remained at this concentration. SPM concentration remained less than $2 \mathrm{mg}^{-1}$ at the surface and $35 \mathrm{~m}$ from the beginning of April 2008 to the end of monitoring in July 2008.
The concentration of dissolved oxygen at $35 \mathrm{~m}$ and $45 \mathrm{~m}$ during the winter (November to March) was between $8.0 \mathrm{mg}^{-1}$ and $9.8 \mathrm{mgl}^{-1}$ (Fig. 2d). In 2007, the concentration at $35 \mathrm{~m}$ decreased from 4 April to a minimum of $6.3 \mathrm{mgl}^{-1}$ on 28 August (79\% saturation, Fig. 2e) after which there was a rapid increase in oxygen concentration over 4 days to $7.9 \mathrm{mg} \mathrm{l}^{-1}$ (saturated with respect to salinity and temperature) on 11 September. Thereafter, the water remained saturated with respect to oxygen, with the concentration increasing over winter as water temperature decreased. Dissolved oxygen concentration at the seabed was $9.0 \mathrm{mg} \mathrm{l}^{-1}$ (97\% saturation) when measurements started on 21 April, after the oxygen concentration at $35 \mathrm{~m}$ had already started to decrease. Dissolved oxygen concentration at the seabed decreased to a minimum of $5.2 \mathrm{mg} \mathrm{l}^{-1}$ (60\% saturation) on 10 July. Concentrations remained low until 7 September but increased to become saturated at $8.0 \mathrm{mgl}^{-1}$ on 19 September (exact dates of start of increase not known due to missing data). The oxygen concentration followed the same pattern in 2008 but did not start to decrease until 21 May. The oxygen concentration at both depths reached a minimum on 30 July 2008 of $6.5 \mathrm{mg} \mathrm{l}^{-1}$ (77\% saturation) at $35 \mathrm{~m}$ and $5.4 \mathrm{mg} \mathrm{l}^{-1}$ (63\% saturation) at $45 \mathrm{~m}$. Oxygen concentrations at both depths did not decrease steadily, but were subject to sudden changes including sharp increases at both depths from 20 to 27 June 2007 and 9 to 19 July 2008 and large decreases at $45 \mathrm{~m}$ from 6 to 25 July 2007 and 21 to 30 July 2008 .

During the monitoring period the near-bed maximum daily currents were primarily due to tidal forcing with velocities of $20 \mathrm{~cm} \mathrm{~s}^{-1}$ on neap tides rising to $30 \mathrm{~cm} \mathrm{~s}^{-1}$ on spring 


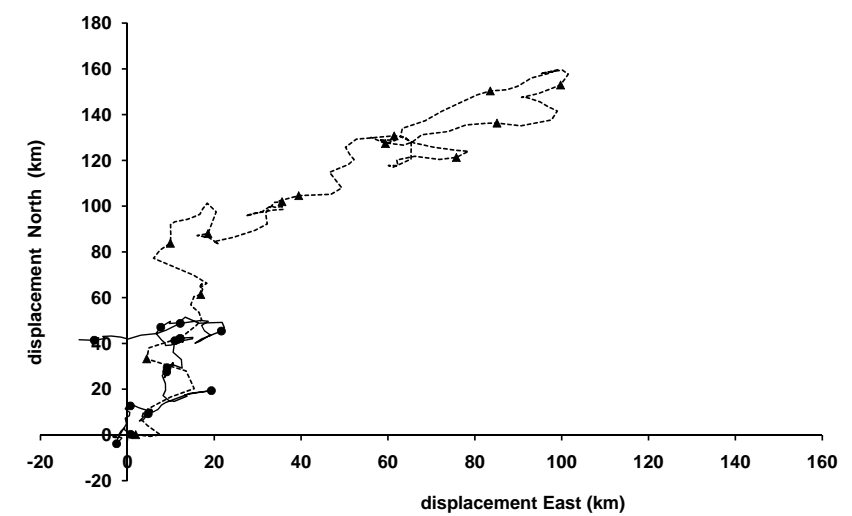

Fig. 3. Progressive vector diagram for Oyster Grounds for May to September 2007. Solid line is $5 \mathrm{~m}$ above seabed, dashed line is $37 \mathrm{~m}$ above seabed. Markers identify every tenth day at each depth.

tides. At the surface corresponding velocities were $25 \mathrm{~cm} \mathrm{~s}^{-1}$ to $35 \mathrm{~cm} \mathrm{~s}^{-1}$ (data not shown) but with greater variability with wind-induced flow giving peaks up to $60 \mathrm{~cm} \mathrm{~s}^{-1}$ (13 June 2007) and $50 \mathrm{~cm} \mathrm{~s}^{-1}$ (17 July 2007). The BML was strongly decoupled from the SML, with low horizontal transport through the site in the BML as evidenced from the progressive vector diagram (Fig. 3) with an equivalent residual velocity in the bottom layer of $0.5 \mathrm{~cm} \mathrm{~s}^{-1}$ while the surface was $2.4 \mathrm{~cm} \mathrm{~s}^{-1}$. Data presented in Fig. 3 for May to September 2007 are representative of the data obtained throughout the monitoring period.

\subsection{North Dogger in situ monitoring}

Surface temperatures ranged from $6.7^{\circ} \mathrm{C}$ (March 2008) to $16.8^{\circ} \mathrm{C}$ (August 2008). The water column was well-mixed during winter but became stratified during spring (Fig. 4a). The water column was stratified from 14 April 2007 and stratification occurred later in 2008, from 25 April 2008. The surface to bottom temperature difference increased more rapidly in 2008 compared to 2007 and there was a greater maximum surface to bottom temperature difference in 2008; the maximum temperature difference was $9.8^{\circ} \mathrm{C}$ on 7 August 2008 compared to $8.1^{\circ} \mathrm{C}$ on 12 August 2007. The temperature of the water at $85 \mathrm{~m}$ increased steadily in both years in contrast to the temperature at the surface and at $31 \mathrm{~m}$ which was subject to more variability. Rapid variations in temperature at $31 \mathrm{~m}$ were associated with storm events observed in the wave height record (Fig. 5). Decreasing temperature at the surface and increasing temperature at $31 \mathrm{~m}$ resulted in the water column becoming mixed down to at least $31 \mathrm{~m}$ on 1 September 2007. In 2007, the whole water column became mixed between 10 and 12 November and the temperatures at all three depths remained within $0.1^{\circ} \mathrm{C}$ of each other for the rest of 2007. In 2008, the water column was still stratified when monitoring ceased on 14 September, with the thermocline above $31 \mathrm{~m}$.
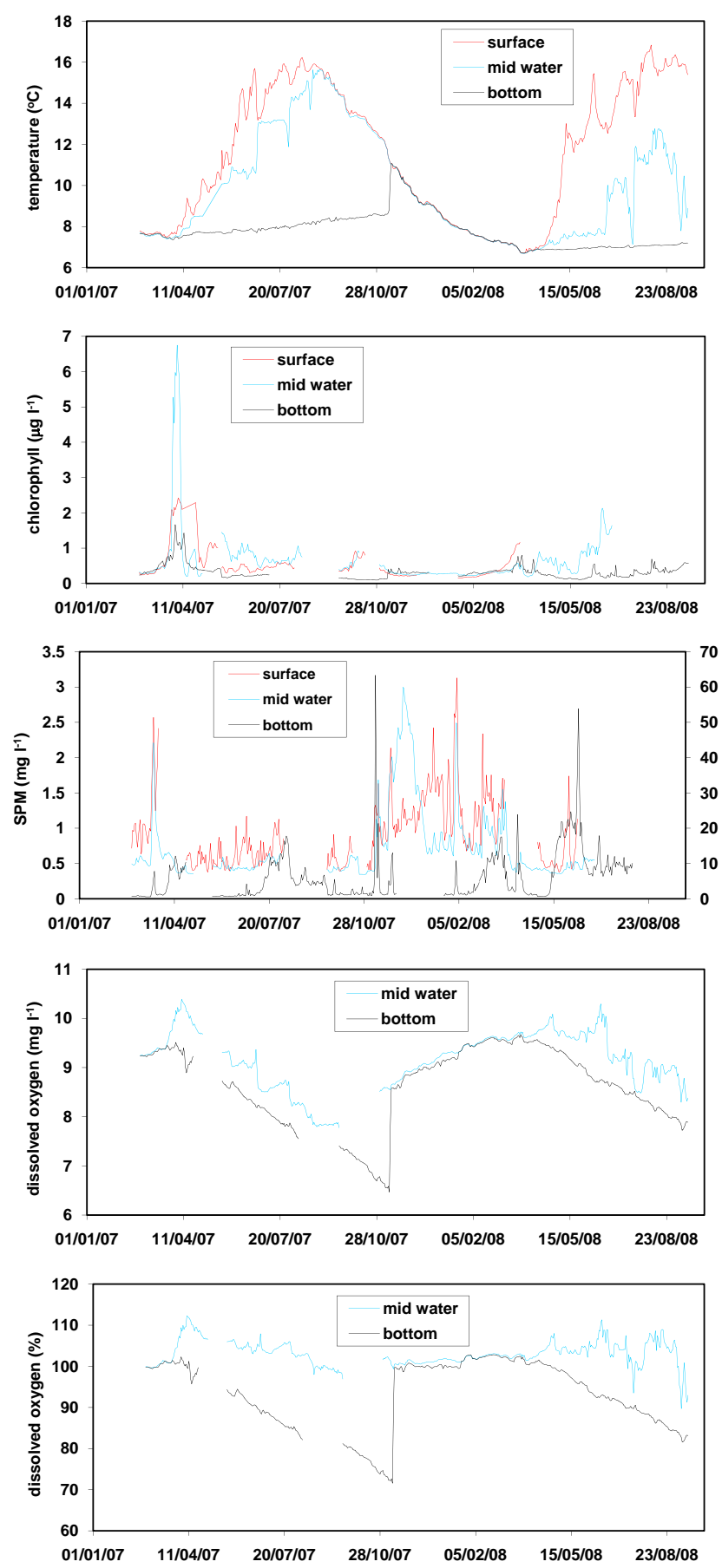

Fig. 4. Mooring data from North Dogger for (a) temperature, (b) chlorophyll, (c) SPM (surface and mid-water on primary y axis, bottom on secondary y axis), (d) oxygen concentration and (e) oxygen percent saturation.

Chlorophyll concentrations were $0.3 \mu \mathrm{g} \mathrm{l}^{-1}$ at all sampling depths at the start of 2007 (Fig. 4b). Chlorophyll concentrations increased at all depths from 28 March 2007, reaching maximum concentrations in early April of $2.4 \mu \mathrm{g} 1^{-1}$ at the surface, $6.7 \mu \mathrm{g} \mathrm{l^{-1 }}$ at $31 \mathrm{~m}$ and $1.7 \mu \mathrm{g}{ }^{-1}$ at $85 \mathrm{~m}$. Thereafter 


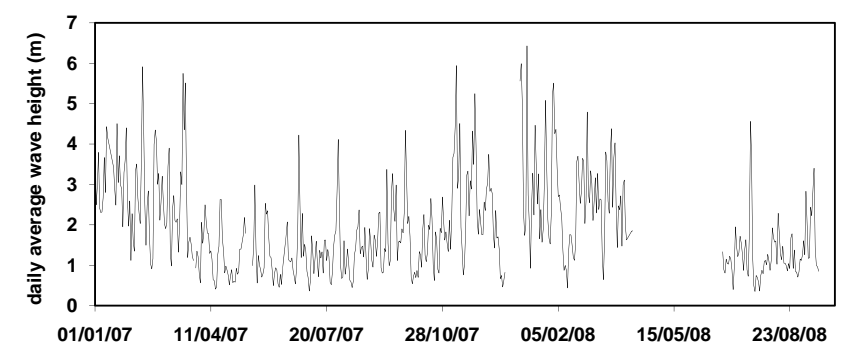

Fig. 5. Daily average wave height at Anasuria $\left(57^{\circ} 15^{\prime} 38 \mathrm{~N}\right.$, $\left.000^{\circ} 48^{\prime} 48 \mathrm{E}\right)$.

chlorophyll concentration at $85 \mathrm{~m}$ decreased to less than $0.5 \mu \mathrm{g} 1^{-1}$ and remained below this for the rest of the year. Chlorophyll concentrations at the surface and $31 \mathrm{~m}$ decreased to less than $1 \mu \mathrm{g} l^{-1}$ by the end of April and stayed at or slightly above this concentration until the end of September, with higher chlorophyll at $31 \mathrm{~m}$ than at the surface. Chlorophyll concentrations at all three depths returned to $0.3 \mu \mathrm{g} 1^{-1}$ after 10 November 2007. Chlorophyll concentration at the surface started to increase from 7 March 2008. The chlorophyll concentration at $31 \mathrm{~m}$ and $85 \mathrm{~m}$ increased to a maximum of $0.8 \mu \mathrm{g} 1^{-1}$ between 22 and 28 March 2008. The concentration of chlorophyll at $85 \mathrm{~m}$ remained below $0.6 \mu \mathrm{g} 1^{-1}$ for the rest of the monitoring period. The chlorophyll concentration at $31 \mathrm{~m}$ increased from 8 April to a maximum of $2.3 \mu \mathrm{g} 1^{-1}$ until the onset of fouling on 27 June.

SPM concentration was generally low at the surface and at $31 \mathrm{~m}$, typically between $0.5 \mathrm{mg} \mathrm{l}^{-1}$ to $1 \mathrm{mg} \mathrm{l}^{-1}$ between May and October and between 1 and $3 \mathrm{mg} \mathrm{l}^{-1}$ between November and April (Fig. 4c). Large fluctuations in SPM concentration were observed at the seabed, with background concentrations between 0.5 and $1 \mathrm{mg}^{-1}$ but several large peaks in both years. There were peaks between mid March and mid April 2007 and between mid July and mid September 2007 which reached a maximum of $17 \mathrm{mg} \mathrm{l}^{-1}$. There was a very sharp increase in SPM concentration between 8 and 14 November which reached a maximum of $63.3 \mathrm{mg} \mathrm{l}^{-1}$. During 2008, peaks in SPM concentration were observed between mid February and mid April and from mid May to the end of monitoring in mid September.

The concentration of dissolved oxygen at $31 \mathrm{~m}$ and $85 \mathrm{~m}$ when measurements started in February was between 9.2 and $9.4 \mathrm{mg}^{-1}$ (saturated, Fig. $4 \mathrm{~d}$ and e). Dissolved oxygen at $31 \mathrm{~m}$ increased from $9.4 \mathrm{mg} \mathrm{l}^{-1}$ on 25 March 2008 to $10.3 \mathrm{mgl}^{-1}$ (109\% saturation) on 9 April 2008. Thereafter oxygen concentration at $31 \mathrm{~m}$ decreased in a series of step changes to $7.7 \mathrm{mgl}^{-1}$ (96\% saturation) on 19 September 2007. There was a small minimum in dissolved oxygen concentration at $85 \mathrm{~m}$ on 15 April then the concentration temporarily recovered. Dissolved oxygen concentrations at $85 \mathrm{~m}$ then decreased steadily to $6.4 \mathrm{mg} \mathrm{l}^{-1}$ ( $71 \%$ saturation) on 10 November 2007. There was a rapid increase in oxygen concentration at $85 \mathrm{~m}$ between 10 and 12 November to

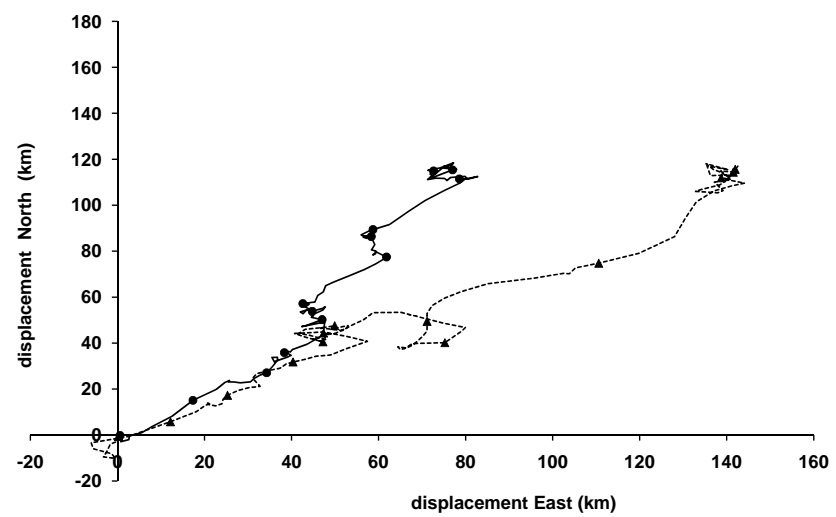

Fig. 6. Progressive vector diagram for North Dogger for May to September 2007. Solid line is $5 \mathrm{~m}$ above seabed, dashed line is $66 \mathrm{~m}$ above seabed. Markers identify every tenth day at each depth.

$8.5 \mathrm{mg}^{-1}$ (saturated) the same as at $31 \mathrm{~m}$. Thereafter the water remained saturated until the beginning of April 2008. Dissolved oxygen at $31 \mathrm{~m}$ increased from the start of April 2008 to a maximum of $10.2 \mathrm{mg}^{-1}$ (111\% saturation) on 16 June 2008 then decreased to a minimum of $8.3 \mathrm{mg} \mathrm{l}^{-1}$ (92\% saturation) when monitoring finished in mid September 2008. Dissolved oxygen at $85 \mathrm{~m}$ decreased steadily from the start of April 2008 to a minimum of $7.8 \mathrm{mg} \mathrm{l}^{-1} 1$ (83\% saturation) at the end of monitoring.

The daily average current speed ranged between $6 \mathrm{~cm} \mathrm{~s}^{-1}$ and $24 \mathrm{~cm} \mathrm{~s}^{-1}$ during the monitoring period. The BML was weakly decoupled from the SML, with lower horizontal transport through the site in the BML compared to the SML (Fig. 6) and with less variability in the lower layer. Data presented in Fig. 6 for May to September 2007 are representative of the data obtained throughout the monitoring period.

\subsection{Principal component analysis}

A correlation-based principal components analysis (PCA) using normalised Euclidean distance was applied to bottom data for temperature, SPM, dissolved oxygen, daily maximum current magnitude for each site, and wave height at the Anasuria platform using Primer version 6.1.5 (Clarke and Warwick, 1994) in order to investigate the relationship between the variables measured. The first two components explained $69.4 \%$ (PC1 37.6\%, PC2 31.8\%) of the variability observed in the Oyster Grounds data. PC1 contrasted samples with increasing temperature and decreasing oxygen and PC2 ordered the samples according to maximum current speed, SPM and wave height (Table 2). Samples with higher temperatures and low oxygen concentration, associated with a stratified water column, were clearly separated from those with lower temperatures and higher oxygen concentration, associated with a well mixed water column (Fig. 7a). The exception to this was a group of samples in mixed conditions which appeared amongst the stratified samples. These were 
samples from November when the water column was still cooling down and oxygen concentrations were increasing.

The first two components explained $60.7 \%$ (PC1 35.7\%, PC2 $25.0 \%$ ) of the variability observed in the North Dogger data. PC1 ordered samples according to maximum current speed and wave height and PC2 contrasted samples with increasing SPM and decreasing oxygen (Table 2). Samples with low oxygen and current magnitudes and high SPM were clearly separated from those with low SPM and higher oxygen concentration and current magnitude (Fig. 7b). There was a discrete group of mixed samples from November when the temperature of the water and the oxygen concentration increased over two days after a storm surge which resulted in a mixed water column. Both sites had outliers associated with the storm surge and these are highlighted in the black oval.

\section{Discussion}

\subsection{New insights from moorings}

Results presented in this study reveal in detail, for the first time, the development of oxygen depletion in stratified offshore areas of the North Sea. The high-frequency data provide insights into the timescales over which oxygen concentrations change with depth in the water column. Both sites showed a reduction in bottom oxygen concentration throughout the summer period. Reduced oxygen concentrations in bottom water from ship-based studies have been previously reported at and near Oyster Grounds (Postma and Rommets, 1984; Peeters et al., 1995; Boers, 2005) and North Dogger (Gehrke (1916) in Postma and Rommets, 1984) and model results have predicted low oxygen concentrations (Los et al., 2008). However, to our knowledge, these data are the first published continuous measurements of bottom oxygen concentrations at these sites in a European shelf sea, which show the environmental conditions leading to decreasing bottom oxygen concentrations.

The oxygen concentrations presented here are consistent with the range of concentrations previously reported in the literature for these areas of the North Sea; at the Oyster Grounds, Postma and Rommets (1984) reported 70\% oxygen saturation in August 1976, De Wilde et al. (1981) reported $46 \%$ oxygen saturation in September 1981, Peeters et al. (1995) reported bottom oxygen concentrations of $\sim 6.5 \mathrm{mg} \mathrm{l}^{-1}$ and $\sim 4.5 \mathrm{mg} \mathrm{l}^{-1}$ in summer 1988 and 1989 respectively and Boers (2005) reported $\sim 3.2 \mathrm{mg} \mathrm{l}^{-1}$ in September 2003. In 2003, very calm and warm weather dominated during the summer and stratification at this site was maintained beyond 3 October (Weston et al., 2008) which is approximately one month longer than measured in our study. This prolonged period of stratification would have maintained an isolated bottom pool of water for a longer period and led to lower bottom oxygen concentrations as shown by Boers (2005) and Weston et al. (2008). The seasonal nature
Table 2. Eigenvectors for PC1 and PC2 for Principal Components Analysis. O2CONC is oxygen concentration $\left(\mathrm{mg} \mathrm{l}^{-1}\right)$; TEMP is temperature $\left({ }^{\circ} \mathrm{C}\right)$; WAVEHT is wave height $(\mathrm{m})$; MAXMAG is maximum daily average current speed $\left(\mathrm{m} \mathrm{s}^{-1}\right)$; SPM is suspended particulate matter $\left(\mathrm{mg} \mathrm{l}^{-1}\right)$.

\begin{tabular}{lrrrr}
\hline \multirow{2}{*}{ variable } & \multicolumn{2}{c}{ Oyster Grounds } & \multicolumn{2}{c}{ North Dogger } \\
& PC1 & PC2 & PC1 & PC2 \\
\hline MAXMAG & -0.081 & -0.615 & 0.644 & 0.073 \\
O2CONC & -0.697 & -0.044 & 0.368 & -0.603 \\
SPM & 0.180 & -0.548 & 0.008 & 0.753 \\
TEMP & 0.662 & -0.132 & 0.213 & 0.099 \\
WAVEHT & -0.192 & -0.550 & 0.636 & 0.233 \\
\hline
\end{tabular}

of oxygen depletion observed in this study is typical of stratified areas (Kemp et al., 2009). Although a consistent seasonal feature each year, the nature of the observed oxygen depletion and minimum concentration varies between years.

During the period 7-10 November a strong storm passed across the North Sea and caused high waves and a storm surge down the North Sea resulting in elevations of up to $2.4 \mathrm{~m}$ at Sheerness in Kent (Met Office, 2007) at a 30 year high. Peak near-bed currents observed in this storm at the stratified North Dogger were $40 \mathrm{~cm} \mathrm{~s}^{-1}$ (data not shown) and the storm resulted in the complete turnover of the water column, the rapid increase in dissolved oxygen concentrations and elevated SPM concentration above the seabed. Elevated SPM concentration was also observed above the seabed at the Oyster Grounds (Fig. 2c). It is only through the use of high frequency fixed point monitoring that detection of short lived episodic events of this nature can be detected. This event is likely to have been missed by ship-based surveys as noted by Mills et al. (2002) using similar approaches in shallow Dutch coastal waters; results from moorings were obtained at wind force 10 when observations from research vessels were unlikely to have been made under such sea conditions.

Whilst bottom oxygen decrease during spring-summer was common to both sites, there was a contrast in how variable the depletion was between sites. The bottom oxygen concentration at the Oyster Grounds showed a decrease from the onset of stratification but this rate of decrease varied in response to changing physical and meteorological conditions. This was in contrast to North Dogger where there was a generally steady decrease in bottom oxygen concentration. The greater depth at North Dogger lead to continuous isolation of the bottom water from the onset of stratification in 2007 until the water column was completely mixed in the autumn due to a storm in November 2007. Vertical mixing events observed in the temperature record at $31 \mathrm{~m}$ during 2007 did not penetrate to the seabed so the BML remained isolated from the storm-induced mixing in the SML. The current meter data at the Oyster Grounds showed that there was a decoupling 

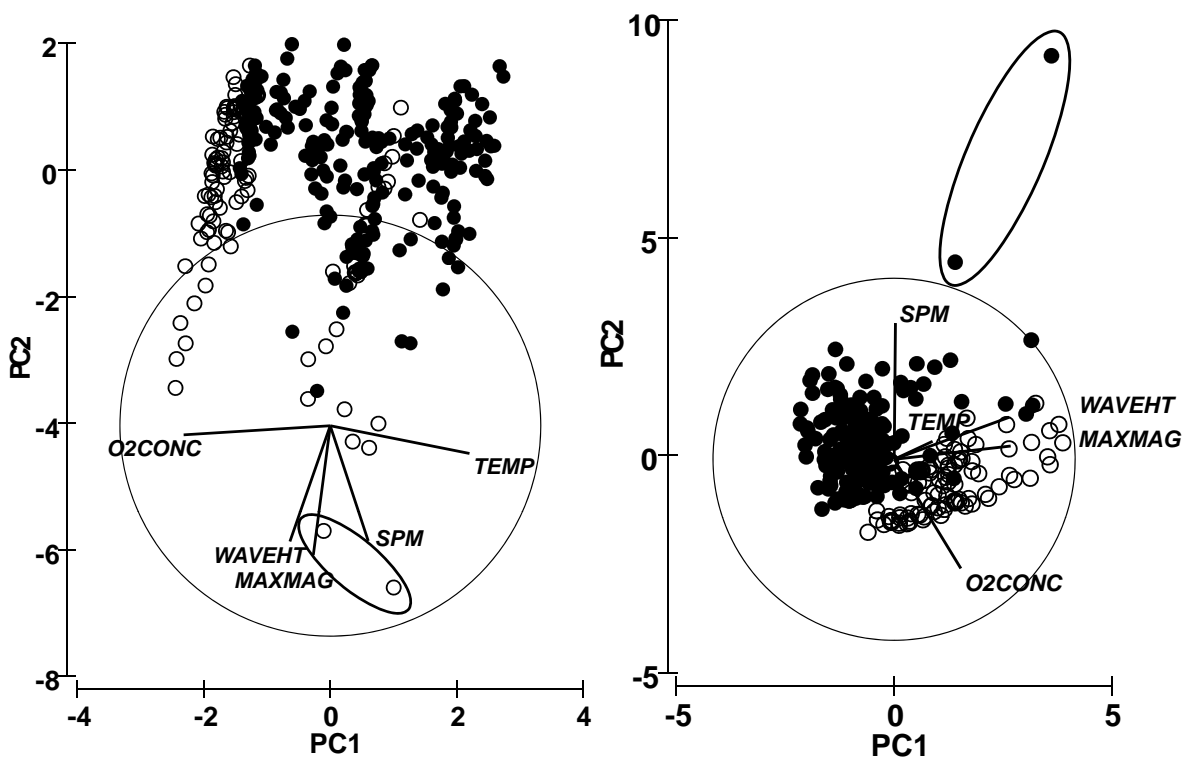

Fig. 7. Principal component analysis for (a) Oyster Grounds and (b) North Dogger. Open circles denote samples under mixed condition, closed circles represent samples under stratified conditions. O2CONC is oxygen concentration ( $\left.\mathrm{mg} \mathrm{l}^{-1}\right)$; TEMP is temperature $\left({ }^{\circ} \mathrm{C}\right)$; WAVEHT is wave height (m); MAXMAG is maximum daily average current speed $\left(\mathrm{m} \mathrm{s}^{-1}\right)$; SPM is suspended particulate matter (mg $\mathrm{l}^{-1}$ ).

between the SML and BML, with minimal horizontal transport through the site in the BML compared with the SML. These types of decoupling events can introduce sheer along the thermocline and can provide a mechanism for nutrient injection into the base of the thermocline which may stimulate increased growth (Sharples et al., 2007). At North Dogger, the water column was less strongly decoupled than at the Oyster Grounds, with less sheer between the SML and BML than at the Oyster Grounds.

This study demonstrates that the depth at which measurements are made is vital to observing the minimum oxygen concentration in the water column. The tether and lander observations were made $10 \mathrm{~m}$ apart in the water column at the Oyster Grounds but differences were observed between these depths. Whilst the temperature observations at each were similar, the oxygen concentrations between these depths differed by as much as $1.9 \mathrm{mgl}^{-1}$.

There were large inter-annual variations in oxygen concentrations observed at both sites during the monitoring period which reflected the different environmental conditions experienced between years. For example, the temperature record shows that storm events at North Dogger (e.g. 26 June 2007 and 29 July 2007) were sufficient to mix the water down to at least $31 \mathrm{~m}$ in 2007 but not to the seabed. In contrast, mixing penetrated further into the water column in 2008 (e.g. 20 July 2008 and 7 September 2008) resulting periodically in similar water temperature at $31 \mathrm{~m}$ and the seabed and a highly variable temperature record at $31 \mathrm{~m}$ in 2008 compared to 2007 .

\subsection{Potential mechanisms for oxygen depletion at the study sites}

The concentration of dissolved oxygen in the water column may be affected by many physical and biological processes. The data presented allow an improved examination of some of these processes and they are addressed below.

\subsubsection{Temperature}

The solubility of oxygen varies with salinity, temperature and pressure (Garcia and Gordon, 1992) and an increase in water temperature will lead to a decrease in oxygen saturation. Both sites exhibited an overall gradual decrease in oxygen saturation through the stratified periods in 2007 and 2008. In 2007 , the underlying decrease in oxygen concentration at the seabed at the Oyster Grounds was $3.3 \mathrm{mg}^{-1}$ and the increase in temperature was $10.0^{\circ} \mathrm{C}$ (Table 3). Assuming a constant salinity and pressure, this would lead to a decrease in oxygen concentration of $1.82 \mathrm{mgl}^{-1}$ (i.e. $55 \%$ of the observed decrease). At the North Dogger, the observed decrease in oxygen concentration was $3.0 \mathrm{mgl}^{-1}$ and the increase in temperature was $1.4^{\circ} \mathrm{C}$ (Table 3). Again, assuming a constant salinity and pressure, this would lead to a decrease in oxygen concentration of $0.29 \mathrm{mg} \mathrm{l}^{-1}$ (i.e. $10 \%$ of the observed decrease). Increasing temperature therefore accounted for $55 \%$ of the decrease in oxygen concentration at Oyster Grounds compared to $10 \%$ at the North Dogger. 
Table 3. Contribution of increasing temperature on decreasing oxygen concentration in the bottom mixed layer at Oyster Grounds and North Dogger.

\begin{tabular}{|c|c|c|c|c|c|c|}
\hline & \multicolumn{3}{|c|}{ Oyster Grounds } & \multicolumn{3}{|c|}{ North Dogger } \\
\hline & & $\begin{array}{c}\mathrm{O}_{2} \\
\left(\mathrm{mg} \mathrm{l}^{-1}\right)\end{array}$ & $\begin{array}{c}\text { Temperature } \\
\left({ }^{\circ} \mathrm{C}\right)\end{array}$ & & $\begin{array}{c}\mathrm{O}_{2} \\
\left(\mathrm{mg} \mathrm{l}^{-1}\right)\end{array}$ & $\begin{array}{c}\text { Temperature } \\
\left({ }^{\circ} \mathrm{C}\right)\end{array}$ \\
\hline Start date & $22 / 04 / 07$ & 8.9 & 6.5 & 05/04/07 & 9.4 & 7.4 \\
\hline End date & 07/09/07 & 5.6 & 16.5 & $10 / 11 / 07$ & 6.4 & 8.8 \\
\hline Observed change & & -3.3 & +10.0 & & -3.0 & +1.4 \\
\hline Number of days & 138 & & & 219 & & \\
\hline Theoretical decrease in oxygen ${ }^{a}$ & & 1.82 & & & 0.29 & \\
\hline Decrease in oxygen concentration due to temperature & & $55 \%$ & & & $10 \%$ & \\
\hline
\end{tabular}

a Assuming a constant salinity and pressure, this is the decrease in oxygen expected due to the observed increase in temperature, calculated according to Garcia and Gordon (1992).

\subsubsection{Remineralisation of organic carbon}

In addition to solubility changes, the decrease in oxygen saturation may be associated with remineralisation of carbon from primary production exported to the BML from the surface or DCM. Published estimates for primary production at Oyster Grounds of $100 \mathrm{~g} \mathrm{C} \mathrm{m}^{-2} \mathrm{yr}^{-1}\left(274 \mathrm{mg} \mathrm{C} \mathrm{m}^{-2}\right.$ day $\left.^{-1}\right)$ and $250 \mathrm{~g} \mathrm{C} \mathrm{m}^{-2} \mathrm{yr}^{-1}\left(685 \mathrm{mg} \mathrm{C} \mathrm{m}^{-2}\right.$ day $\left.^{-1}\right)$ were taken from Joint and Pomroy (1993) and Gieskes and Kraay (1984) respectively. At the Oyster Grounds there was a decrease of $3.4 \times 10^{-7} \mathrm{~mol} \mathrm{O}_{2} 1^{-1} \mathrm{day}^{-1}$ due to processes other than increasing temperature (Table 4). Assuming a BML depth of $25 \mathrm{~m}$ and integrating for $1 \mathrm{~m}^{2}$ of water column, this gives $8.5 \mathrm{mmol} \mathrm{O}_{2} \mathrm{~m}^{-2}$ day $^{-1}$ which would require remineralisation of $102 \mathrm{mg} \mathrm{C} \mathrm{m}^{-2} \mathrm{day}^{-1}$. This is between $15 \%$ and $37 \%$ of the water column integrated primary production determined by Gieskes and Kraay (1984) and Joint and Pomroy (1993), respectively.

The sharpest decrease in oxygen observed during one of the "events" at the Oyster Grounds was $0.22 \mathrm{mg} \mathrm{O}_{2} \mathrm{l}^{-1}$ day $^{-1}$ $\left(7.0 \times 10^{-6} \mathrm{~mol} \mathrm{O}_{2} \mathrm{l}^{-1} \mathrm{day}^{-1}\right.$, Table 5). Assuming a BML thickness of $25 \mathrm{~m}$ and integrating for $1 \mathrm{~m}^{2}$ of water column, this gives $0.17 \mathrm{~mol} \mathrm{O}_{2} \mathrm{~m}^{-2} \mathrm{day}^{-1}$ which would equate to a primary production of $2.1 \mathrm{~g} \mathrm{C} \mathrm{m}^{-2} \mathrm{day}^{-1}$. In order to create this type of pulsed oxygen demand there would have to be increased supply of nutrient expected to sustain increased production. This could be linked to highly episodic wind driven events and increased sheer which would increase the nutrient flux into or across the thermocline (Sharples et al., 2007). When this localised nutrient is then exhausted the phytoplankton growth ceases and sinks to the BML resulting in an intense oxygen demand.

An estimate of $740.9 \mathrm{mg} \mathrm{C} \mathrm{m}^{-2}$ day $^{-1}$ integrated water column primary production for a stratified site north of Dogger Bank was taken from Weston et al. (2005) and an estimate of 150 to $200 \mathrm{~g} \mathrm{C} \mathrm{m}^{-2} \mathrm{yr}^{-1}$ (411 to $548 \mathrm{mg} \mathrm{C} \mathrm{m}^{-2} \mathrm{day}^{-1}$ ) for the northern North Sea from Reid et al. (1990). At North
Dogger there was a decrease of $3.8 \times 10^{-7} \mathrm{~mol} \mathrm{O}_{2} \mathrm{l}^{-1}$ day $^{-1}$ due to processes other than increasing temperature (Table 4). Assuming a BML depth of $40 \mathrm{~m}$ and integrating for $1 \mathrm{~m}^{2}$ of water column, this gives $15.0 \mathrm{mmol} \mathrm{O}_{2} \mathrm{~m}^{-2}$ day $^{-1}$ which would require remineralisation of $180 \mathrm{mg} \mathrm{C} \mathrm{m}^{-2} \mathrm{day}^{-1}$. This is $24 \%$ of the water column integrated primary production from Weston et al. (2005) and between $32 \%$ and $44 \%$ of the values from Reid et al. (1990). The North Dogger site would therefore require remineralisation of a greater amount of water column primary production than the Oyster Grounds to create the remaining oxygen demand after the affect of increasing temperature has been accounted for.

\subsubsection{Remineralisation of suspended particulate organic matter}

Another potential mechanism to create event draw down of oxygen would be from resuspension of organic material (i.e. sediment or benthic fluff) due to natural storm events or human activities such as trawling. Depending on the sediment type, depth of sediment eroded/resuspended and carbon content of the sediment it would be possible to create a substantial oxygen demand from oxidation of reduced chemical species (including nutrients) or indirectly through resuspension of organic carbon, sediment or benthic fluff, which can then be aerobically respired (Jago and Jones, 1998; Van Raaphorst et al., 1998). Van Raaphorst et al. (1998) demonstrated the importance of the Oyster Grounds and other similar depocentre areas in the carbon budget of the North Sea. They found there was a highly dynamic exchange of particles between the sediment and water column and this would create an oxygen demand upon aerobic respiration of the suspended material.

The trawling intensity and distribution is patchy in the North Sea (Rijnsdorp et al., 1998; Trimmer et al., 2005; Jennings et al., 1999). Data from these studies showed that both sites are subject to trawling which will create an oxygen 
Table 4. Estimates of carbon remineralisation accounted for by overall decrease in oxygen concentration at Oyster Grounds and North Dogger.

\begin{tabular}{lcc}
\hline & Oyster Grounds & North Dogger \\
\hline Decrease in oxygen not accounted for by temperature $\left(\mathrm{mg} \mathrm{l}^{-1}\right)$ & 1.5 & 2.7 \\
Number of days (days) & 138 & 219 \\
Rate of decrease in oxygen concentration $\left(\mathrm{mg} \mathrm{l}^{-1} \mathrm{day}^{-1}\right)$ & 0.011 & 0.012 \\
Rate of decrease in oxygen concentration $\left(\mathrm{mol} \mathrm{l}^{-1} \mathrm{day}^{-1}\right)$ & $3.4 \times 10^{-7}$ & $3.8 \times 10^{-7}$ \\
Depth of BML (m) & 25 & 40 \\
Volume of BML in 1 $\mathrm{m}^{2}$ water column $\left(\mathrm{m}^{-2}\right)$ & 25000 & 40000 \\
Rate of decrease in oxygen concentration in BML $\left(\mathrm{mol} \mathrm{m}^{-2} \mathrm{day}^{-1}\right)$ & $8.5 \times 10^{-3}$ & $1.5 \times 10^{-2}$ \\
Rate of carbon remineralisation $\left(\mathrm{mol} \mathrm{m}^{-2} \mathrm{day}^{-1}\right)^{\mathrm{a}}$ & $8.5 \times 10^{-3}$ & $1.5 \times 10^{-2}$ \\
Rate of carbon remineralisation $\left(\mathrm{mg} \mathrm{C} \mathrm{m}^{-2} \mathrm{day}^{-1}\right)^{\mathrm{a}}$ & 102 & 180 \\
\hline
\end{tabular}

a Assuming that all decrease in oxygen is due to remineralisation of carbon.

Table 5. Estimate of carbon remineralisation accounted for by pulsed decrease in oxygen concentration at Oyster Grounds.

\begin{tabular}{lcc}
\hline & \multicolumn{2}{c}{ Oyster Grounds } \\
\hline Oxygen concentration at start date $\left(\mathrm{mg} \mathrm{l}^{-1}\right)$ & $03 / 07 / 07$ & 6.8 \\
Oxygen concentration at end date $\left(\mathrm{mg} \mathrm{l}^{-1}\right)$ & $10 / 07 / 07$ & 5.2 \\
Observed decrease in oxygen $\left(\mathrm{mg}^{-1}\right)$ & 7.6 \\
Number of days (days) & 7 \\
Rate of decrease in oxygen concentration $\left(\mathrm{mg} \mathrm{l}^{-1} \mathrm{day}^{-1}\right)$ & 0.22 \\
Rate of decrease in oxygen concentration $\left(\mathrm{mol} \mathrm{l}^{-1} \mathrm{day}^{-1}\right)$ & $7.0 \times 10^{-6}$ \\
Depth of BML $(\mathrm{m})$ & 25 \\
Volume of BML in $1 \mathrm{~m}^{2}$ water column $\left(\mathrm{l} \mathrm{m}^{-2}\right)$ & 25000 \\
Rate of decrease in oxygen concentration in BML $\left(\mathrm{mol} \mathrm{m}^{-2} \mathrm{day}^{-1}\right)$ & 0.17 \\
Rate of carbon remineralisation $\left(\mathrm{mol} \mathrm{m}^{-2} \mathrm{day}^{-1}\right)^{\mathrm{a}}$ & 0.17 \\
Rate of carbon remineralisation $\left(\mathrm{g} \mathrm{C} \mathrm{m}^{-2} \mathrm{day}^{-1}\right)^{\mathrm{a}}$ & 2.1 \\
\hline
\end{tabular}

a Assuming that all decrease in oxygen is due to remineralisation of carbon.

demand as surface sediment is mixed in the overlying water and in addition will have an impact on the sediment biogeochemistry and ecosystem integrity (Trimmer et al., 2005; Allen and Clarke, 2007). To estimate the volume of sediment disturbed by trawling, the benthic trawling activity $\left(\mathrm{h} \mathrm{yr}^{-1}\right)$ of the UK fishing fleet greater than $15 \mathrm{~m}$ length using otter trawls and beam trawls were obtained from Vessel Monitoring System (VMS) data (Lee et al., 2010) for 2007 and 2008. Data was summed for both trawl types in a one-degree box centred on each site (Table 6). The maximum speed of towing for otter trawls and beam trawls were considered to be 4 knots $\left(7.4 \mathrm{~km} \mathrm{~h}^{-1}\right)$ and 6 knots $\left(11.1 \mathrm{~km} \mathrm{~h}^{-1}\right)$ respectively (Lee et al., 2010), the gear width of otter trawls and beam trawls were $4 \mathrm{~m}$ and $24 \mathrm{~m}$ respectively (Eastwood et al., 2007) and the depth of sediment potentially trawled by such gear was estimated as $5 \mathrm{~cm}$ (Trimmer et al., 2005). Using these data, estimates of the volume of sediment trawled by the UK fleet in each one-degree box were calculated to be $1.8 \times 10^{7} \mathrm{~m}^{3}$ and $3.3 \times 10^{7} \mathrm{~m}^{3}$ at the Oyster Grounds in 2007 and 2008 respectively and $3.9 \times 10^{7} \mathrm{~m}^{3}$ and $3.6 \times 10^{7} \mathrm{~m}^{3}$ at North Dogger in 2007 and 2008 respectively (Table 6). Although not all of this trawled sediment will enter the water column, it gives an estimate of the amount of sediment exposed to the overlying water through such activities. The total volume of sediment disturbed by the international fleet in each area will be larger than the estimates of the UK fleet alone and therefore the numbers presented here may be considered underestimates.

\subsubsection{Advection}

As indicated in the progressive vector diagrams (Figs. 3 and 6) and summarised in Table 7, the advection in the BML of the Oyster Ground is very low as it is an area which is surrounded by bottom fronts (Weston et al., 2008). In order for a relatively small region such as the Oyster Ground to remain well stratified, then advection across bottom fronts has to be minimal (Hill et al., 1996). This slow advection rate in the bottom layer results in very little horizontal exchange 
Table 6. Estimates of the volume of sediment trawled at Oyster Grounds and North Dogger in 2007 and 2008 by the UK over $15 \mathrm{~m}$ fishing fleet.

\begin{tabular}{lcccc}
\hline & \multicolumn{2}{c}{ Oyster Grounds } & \multicolumn{2}{c}{ North Dogger } \\
& 2007 & 2008 & 2007 & 2008 \\
\hline Otter trawl fishing activity (hours $\left.\mathrm{yr}^{-1}\right)$ & 0 & 814 & 1535 & 1955 \\
Beam trawl fishing activity (hours yr & & & & \\
Area disturbed, otter trawl $\left(\mathrm{m}^{2} \mathrm{yr}^{-1}\right)$ & 1379 & 2356 & 2748 & 2488 \\
Area disturbed, beam trawl $\left(\mathrm{m}^{2} \mathrm{yr}^{-1}\right)$ & 0 & $2.41 \times 10^{7}$ & $4.55 \times 10^{7}$ & $5.79 \times 10^{7}$ \\
Total area disturbed $\left(\mathrm{m}^{2} \mathrm{yr}^{-1}\right)$ & $36.8 \times 10^{7}$ & $62.8 \times 10^{7}$ & $73.3 \times 10^{7}$ & $66.4 \times 10^{7}$ \\
Proportion of area of one degree box trawled (\%) & $36.8 \times 10^{7}$ & $65.2 \times 10^{7}$ & $77.8 \times 10^{7}$ & $72.1 \times 10^{7}$ \\
Volume of sediment disturbed $\left(\mathrm{m}^{3} \mathrm{yr}^{-1}\right)$ & 4.7 & 8.3 & 10.7 & 9.9 \\
& $1.8 \times 10^{7}$ & $3.3 \times 10^{7}$ & $3.9 \times 10^{7}$ & $3.6 \times 10^{7}$ \\
\hline
\end{tabular}

Table 7. Net average daily advection rates between May and September 2007, calculated from ADCP data. The actual net residual over the 120 day stratified period is less than the daily average.

\begin{tabular}{lcc}
\hline $\begin{array}{l}\text { Height above } \\
\text { seabed }(\mathrm{m})\end{array}$ & $\begin{array}{c}\text { Oyster Ground } \\
\mathrm{km} \mathrm{day}^{-1}\left(\mathrm{~cm} \mathrm{~s}^{-1}\right)\end{array}$ & $\begin{array}{c}\text { North Dogger } \\
\mathrm{km} \mathrm{day}^{-1}\left(\mathrm{~cm} \mathrm{~s}^{-1}\right)\end{array}$ \\
\hline 66 & - & $1.5(1.7)$ \\
37 & $1.5(1.7)$ & - \\
5 & $0.3(0.5)$ & $1.1(1.2)$ \\
\hline
\end{tabular}

and therefore no renewal of the bottom water due to lateral processes. During the period of stratification (138 days) the advection was approximately $50 \mathrm{~km}$, which is significantly smaller than the size of the stratified area. Advection was higher in the SML, where wind forcing is more important, although still low compared to an average advection of $3.2 \mathrm{~cm} \mathrm{~s}^{-1}$ in the southern North Sea (Weston et al., 2004). It is possible that water masses may be transported across the upper layers of fronts and this mechanism may transport nutrient rich water into an area where surface nutrients are depleted. This may enhance local production at the surface and subsurface with the decay of such material, and subsequent oxygen demand, occurring in the bottom layers.

In contrast, the North Dogger site has higher advection rates with similar rates in the upper and lower layers (Table 7). Advection is however lower than advection in the southern North Sea (Weston et al., 2004). This stratified area North of the Dogger Bank extends for many hundreds of kilometres both East and West from the mooring site, thus it is consistent for advection of between $1 \mathrm{~km} \mathrm{day}^{-1}$ and $1.5 \mathrm{~km} \mathrm{day}^{-1}$ to be compatible with the transport of similar type water masses from surrounding stratified areas. Thus while advection does occur it is likely to be of similar types of water masses with similar water properties including dissolved oxygen.

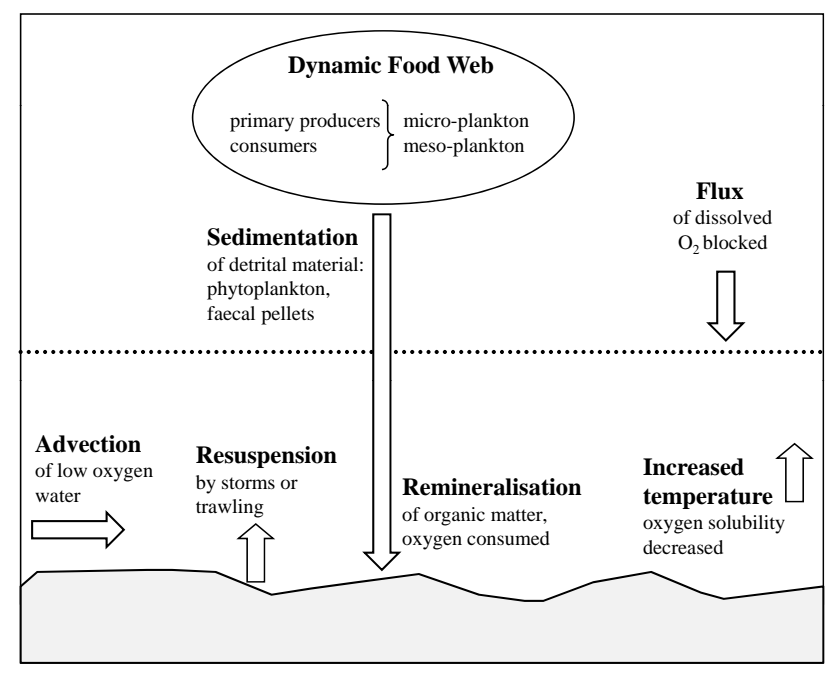

Fig. 8. Summary of processes which influence dissolved oxygen concentration at Oyster Grounds and North Dogger during the stratified period.

The relative contribution of the factors discussed above are summarised for each site in Fig. 8 and Table 8.

\subsection{Implications for marine management}

Climate change scenarios for the North Sea predict that the duration and intensity of stratification will increase (Lowe et al., 2009). These factors will have the potential to augment the decrease in BML oxygen in the seasonally stratified North Sea by increasing the isolation of the BML leading to lower oxygen concentrations. In addition, the number of summer storms may increase under worst case climate change scenarios. Such storms may disturb the seabed and result in increased resuspension of SPM which may further reduce the BML oxygen concentration. However, deepening of the thermocline during storms will act to ventilate the BML due to wind mixing resulting in higher oxygen concentrations. This study has shown the importance of temperature 
Table 8. Summary of the processes controlling the dissolved oxygen concentration at Oyster Grounds and North Dogger.

\begin{tabular}{|c|c|c|}
\hline & Oyster Grounds & North Dogger \\
\hline Remineralisation & $\begin{array}{l}\text { Remineralisation of } 102 \mathrm{mgC} \mathrm{m}^{-2} \\
\text { day }^{-1} \text { (sinking or resuspension) con- } \\
\text { sumes } 1.5 \mathrm{mg}^{-1} \text { oxygen over } 138 \text { days }\end{array}$ & $\begin{array}{l}\text { Remineralisation of } 180 \mathrm{mgC} \mathrm{m}^{-2} \\
\text { day }^{-1} \text { (sinking or resuspension) con- } \\
\text { sumes } 2.7 \mathrm{mg} \mathrm{l}^{-1} \text { oxygen over } 219 \text { days }\end{array}$ \\
\hline Advection & $\begin{array}{l}0.3 \mathrm{~km} \mathrm{~d}^{-1} \text { horizontal advection of low } \\
\text { oxygen water through site }\end{array}$ & $\begin{array}{l}1.1 \mathrm{~km} \mathrm{~d}^{-1} \text { horizontal advection of low } \\
\text { oxygen water through site }\end{array}$ \\
\hline Temperature & $\begin{array}{l}10^{\circ} \mathrm{C} \text { increase in temperature reduces } \\
\text { oxygen by } 1.8 \mathrm{mg} \mathrm{l}^{-1} \text { over } 138 \text { days }\end{array}$ & $\begin{array}{l}1.4^{\circ} \mathrm{C} \text { increase in temperature reduces } \\
\text { oxygen by } 0.3 \mathrm{mg}^{-1} \text { over } 219 \text { days }\end{array}$ \\
\hline Trawling & $\begin{array}{l}\text { Between } 1.8 \times 10^{7} \mathrm{~m}^{3} \text { and } 3.3 \times 10^{7} \mathrm{~m}^{3} \\
\text { sediment trawled by UK vessels }\end{array}$ & $\begin{array}{l}\text { Between } 3.9 \times 10^{7} \mathrm{~m}^{3} \text { and } 3.6 \times 10^{7} \mathrm{~m}^{3} \\
\text { sediment trawled by UK vessels }\end{array}$ \\
\hline
\end{tabular}

in controlling, directly and indirectly, the dissolved oxygen concentration at the Oyster Grounds. It has also shown the difference between study areas with the Oyster Grounds more sensitive to temperature driven changes than the deeper North Dogger site. Future increases in temperatures would therefore have the potential to exacerbate low oxygen conditions at both sites but with a larger impact on the Oyster Grounds.

Under well mixed conditions, nutrients are supplied to the Oyster Grounds from the Southern Bight and coastal waters (Lenhart et al., 2010). However, once stratification occurs, the frontal systems act as a barrier to the exchange of water and thus prevent further supply of nutrients to the site. Therefore during stratified conditions, which are the concern of this paper, the only likely addition of new nutrients that may occur is via atmospheric sources (Jickells, 1995). It is the length of stratification that is likely to be the most important factor in relation to the observed oxygen values and it is therefore expected that impacts due to climate change may be more important in the future.

The significance and factors controlling hypoxia is an area of key concern across the globe (Diaz and Rosenberg, 2008). The use of oxygen as an indicator of ecosystem health, and specifically eutrophication, within marine management systems is well established (Best et al., 2007; Devlin et al., 2007; Heslenfeld and Enserink, 2008; Johnson, 2008) with oxygen depletion below a defined threshold considered to be one of the indicators of undesirable disturbance to ecosystem health (Tett et al., 2007). Whilst these sites are not hypoxic and minimum dissolved oxygen concentrations observed were much greater than the minimum observed in the OMZ in the Pacific and Atlantic Oceans (Karstensen et al., 2008), both the sites in this study exhibited seasonal reduction in dissolved oxygen concentration under stratified conditions and the concentrations observed at Oyster Grounds may be considered "deficient" (OSPAR, 2005). This study has shown that thermal stratification is an important factor determining susceptibility to oxygen depletion, particularly at the Oyster Grounds. In addition, temperature may directly influence observed oxygen concentration through its influence on saturation. Consequently, reduced oxygen concentrations observed at these sites that could be regarded as symptoms of anthropogenically driven eutrophication may arise as a result of natural processes.

\section{Future work}

Work is in progress to quantify the key components within the benthic-pelagic system using results from detailed process studies carried out within this project, which will give greater understanding of the factors controlling oxygen fluxes, a currently understudied parameter. These measurements have been able to provide improved insight into the processes acting on oxygen saturation/concentration at these two sites. However, the processes are complex and further work is required using numerical models to allow further elucidation of the relative significance of the seasonal drivers. Coupled hydrodynamic-ecosystem models are able to reproduce the gradual decrease in oxygen concentration in seasonally stratified areas of the North Sea such as that observed at North Dogger (Lenhart et al., 2010). However, work is still required to more accurately model low oxygen events such as those seen at the Oyster Grounds. Accurate representation of oxygen concentrations is vital to be able to correctly model impacts on ecosystem functioning and on processes such as de-nitrification and nutrient cycling (Trimmer et al., 2005; Middelburg and Levin, 2009). The data obtained in this study will aid the development of models that in the future will allow more accurate predictions of the impact of climate change on oxygen concentrations and ecosystem functioning. 
Further measurements are required to assess the extent in time and space of low oxygen concentrations in the stratified North Sea and other shelf seas. Recent developments in technology such as augmenting gliders with oxygen sensors and future implementation of the same capability on fish tags would provide an effective way of improving our data coverage. Further studies are required to investigate the interacting mechanisms which lead to oxygen depletion at such sites. It has recently been shown that oxygen levels in the north east Atlantic have declined in the past fifty years (Stramma et al., 2008). A greater understanding of the interactions between oceans and shelf seas would enable better predictions of the impacts of changes in ocean oxygen concentrations on shelf seas.

\section{Conclusions}

The dissolved oxygen concentration in the bottom water decreased at both of the study sites under thermally stratified conditions. Decreasing oxygen was driven by increasing temperature and biomass input, the latter which is driven by production during the spring bloom and in the deep chlorophyll maximum and the period of stratification. Increasing temperature of the bottom water at Oyster Grounds accounted for $55 \%$ of the decrease in oxygen concentration at this site compared to $10 \%$ at North Dogger and greater remineralisation of primary production would be required at North Dogger to account for the observed oxygen depletion.

The factors controlling the dissolved oxygen concentration may operate over varying timescales and short term events may be important in affecting the concentration of dissolved oxygen for relatively short durations of time when compared to the seasonal cycle. The relative importance of each factor varies between different regions and therefore management measures must be organised on a regional basis and must be able to monitor changes over a range of time scales. Further measurements over multi-annual timescales and at additional locations of distinct environmental characteristics will be required to provide a fuller understanding of the controls on dissolved oxygen concentration in shelf seas. It is only with this improved understanding and by using approaches such as within this study that healthy shelf seas will be maintained.

Acknowledgements. This work was funded by Defra as part of the ME3205 and SLA25 projects. The mooring at the Oyster Grounds was part of a collaborative project between Cefas and Directorate Noordzee (DNZ). Keith Weston was funded by a NERC grant NE/F001932/1. The authors would like to thank Janette Lee for providing VMS data and comments from Per Hall and Michelle Devlin which greatly improved this manuscript. We would like to thank the officers and crew of the RV Endeavour and MV Zirfaea for their assistance in this work.

Edited by: J. Middelburg

\section{References}

Allen, J. I. and Clarke, K. R.: Effects of demersal trawling on ecosystem functioning in the North Sea: A modelling study, Mar. Ecol. Prog. Ser., 336, 63-75, 2007.

Bendtsen, J., Gustafsson, K. E., Söderkvist, J., and Hansen, J. L. S.: Ventilation of bottom water in the North SeaBaltic Sea transition zone, J. Mar. Syst., 75, 138-149, doi:10.1016/j.jmarsys.2008.08.006, 2009.

Best, M. A., Wither, A. W., and Coates, S.: Dissolved oxygen as a physico-chemical supporting element in the Water Framework Directive, Mar. Pollut. Bull., 55, 53-64, doi:10.1016/j.marpolbul.2006.08.037, 2007.

Boers, M.: Effects of a deep sand extraction pit. Final report of the PUTMOR measurements at the Lowered Dump Site, Rijkswaterstaat, The Netherlands, RIKZ/2005.001, 87, 2005.

Breitburg, D. L., Hondorp, D. W., Davias, L. A., and Diaz, R. J.: Hypoxia, Nitrogen, and Fisheries: Integrating Effects Across Local and Global Landscapes, Ann. Rev. Mar. Sci., 1, 329-349, doi:10.1146/annurev.marine.010908.163754, 2009.

Brown, J., Hill, A. E., Fernand, L., and Horsburgh, K. J.: Observations of a seasonal jet-like circulation at the central North Sea cold pool margin, Estuar. Coast. Shelf Sci., 48, 343-355, doi:10.1006/ecss.1999.0426, 1999.

Chabot, D. and Claireaux, G.: Environmental hypoxia as a metabolic constraint on fish: The case of Atlantic cod, Gadus morhua, Mar. Pollut. Bull., 57, 287-294, doi:10.1016/j.marpolbul.2008.04.001, 2008.

Chan, F., Barth, J. A., Lubchenco, J., Kirincich, A., Weeks, H., Peterson, W. T., and Menge, B. A.: Emergence of anoxia in the California current large marine ecosystem, Science, 319, p. 920, doi:10.1126/science.1149016, 2008.

Cheung, S. G., Chan, H. Y., Liu, C. C., and Shin, P. K. S.: Effect of prolonged hypoxia on food consumption, respiration, growth and reproduction in marine scavenging gastropod Nassarius festivus, Mar. Pollut. Bull., 57, 280-286, doi:10.1016/j.marpolbul.2008.03.039, 2008.

Clarke, K. R. and Warwick, R. M.: Changes in marine communities: an approach to statistical analysis and interpretation, Plymouth Marine Laboratory, Plymouth, UK, 144 pp., 1994.

Colijn, F., Hesse, K., Ladwig, N., and Tillman, U.: Effects of the large-scale uncontrolled fertilisation process along the continental coastal North Sea, Hydrobiologia, 484, 133-148, doi:10.1023/A:1021361206529, 2002.

Conley, D. J., Humborg, C., Rahm, L., Savchuk, O. P., and Wulff, F.: Hypoxia in the baltic sea and basin-scale changes in phosphorus biogeochemistry, Environ. Sci. Technol., 36, 5315-5320, doi:10.1021/es025763w, 2002.

De Jonge, V. N., Bakker, J. F., and Van Stralen, M.: Recent changes in the contributions of river Rhine and north sea to the eutrophication of the western Dutch Wadden Sea, Aquat. Ecol., 30, 27 39, 1996.

De Wilde, P. A. W. J., Berghuis, E. M., and Kok, A.: Structure and energy demand of the benthic community of the oyster ground, central North Sea, Neth. J. Sea Res., 18, 143-159, 1984.

Devlin, M., Painting, S., and Best, M.: Setting nutrient thresholds to support an ecological assessment based on nutrient enrichment, potential primary production and undesirable disturbance, Mar. Pollut. Bull., 55, 65-73, doi:10.1016/j.marpolbul.2006.08.030, 2007. 
Diaz, R. J.: Overview of hypoxia around the world, J. Environ. Qual., 30, 275-281, 2001.

Diaz, R. J. and Rosenberg, R.: Spreading dead zones and consequences for marine ecosystems, Science, 321, 926-929, doi:10.1126/science.1156401, 2008.

Eastwood, P. D., Mills, C. M., Aldridge, J. N., Houghton, C. A., and Rogers, S. I.: Human activities in UK offshore waters: An assessment of direct, physical pressure on the seabed, ICES J. Mar. Sci., 64, 453-463, 2007.

Ekau, W., Auel, H., Pörtner, H.-O., and Gilbert, D.: Impacts of hypoxia on the structure and processes in the pelagic community (zooplankton, macro-invertebrates and fish), Biogeosciences Discuss., 6, 5073-5144, 2009,

http://www.biogeosciences-discuss.net/6/5073/2009/.

EU: Establishing a framework for community action in the field of marine environmental policy (Marine Strategy Framework Directive), The European Parliament and the Council of the European Union, 22, 2008.

Foden, J., Devlin, M. J., Mills, D. K., and Malcolm, S. J.: Searching for undesirable disturbance: an application of the OSPAR eutrophication assessment method to marine waters of England and Wales, Biogeochemistry, accepted, 2010.

Garcia, H. E. and Gordon, L. I.: Oxygen solubility in seawater: better fitting equations, Limnol. Oceanogr., 37, 1307-1312, 1992.

Gehrke, J.: Uber die Sauerstoffverhältnisse in der Nordsee, Ann. Hydrog. Marit. Meterol., 44, 177-193, 1916.

Gieskes, W. W. C. and Kraay, G. W.: Phytoplankton, its pigments, and primary production at a central north sea station in May, July and September 1981, Neth. J. Sea Res., 18, 51-70, 1984.

Hassell, K. L., Coutin, P. C., and Nugegoda, D.: Hypoxia impairs embryo development and survival in black bream (Acanthopagrus butcheri), Mar. Pollut. Bull., 57, 302-306, doi:10.1016/j.marpolbul.2008.02.045, 2008.

Heslenfeld, P. and Enserink, E. L.: OSPAR Ecological Quality Objectives: The utility of health indicators for the North Sea, ICES J. Mar. Sci., 65, 1392-1397, doi:10.1093/icesjms/fsn159, 2008.

Hill, W. H.: Currents and water masses, in: North Sea Science, edited by: Goldberg, E. D., MIT Press, London, 17-42, 1973.

Hill, A. E., Brown, J., and Fernand, L.: The western Irish Sea gyre: A retention system for Norway lobster (Nephrops norvegicus)?, Oceanol. Acta, 19, 357-368, 1996.

Howarth, M. J., Dyer, K. R., Joint, I. R., Hydes, D. J., Purdie, D. A., Edmunds, H., Jones, J. E., Lowry, R. K., Moffat, T. J., Pomeroy, A. J., and Proctor, R.: Seasonal cycles and their spatial variability, in: Understanding the North Sea system, edited by: Charnock, H., Dyer, K. R., Huthnance, J. M., Liss, P. S., Simpson, J. H., and Tett, P. B., Chapman and Hall, London, 5-25, 1993.

Jago, C. F. and Jones, S. E.: Observation and modelling of the dynamics of benthic fluff resuspended from a sandy bed in the southern North Sea, Cont. Shelf Res., 18, 1255-1282, doi:10.1016/S0278-4343(98)00043-0, 1998.

Jennings, S., Alvsvåg, J., Cotter, A. J. R., Ehrich, S., Greenstreet, S. P. R., Jarre-Teichmann, A., Mergardt, N., Rijnsdorp, A. D., and Smedstad, O.: Fishing effects in northeast Atlantic shelf seas: patterns in fishing effort, diversity and community structure. III. International trawling effort in the North Sea: an analysis of spatial and temporal trends, Fish. Res., 40, 125-134, 1999.

Jickells, T. D.: Atmospheric inputs of metals and nutrients to the oceans: their magnitude and effects, Mar. Chem., 48, 199-214, 1995.

Jickells, T. D.: Nutrient biogeochemistry of the coastal zone, Science, 281, 217-222, doi:10.1126/science.281.5374.217, 1998.

Johnson, D.: Environmental indicators: Their utility in meeting the OSPAR Convention's regulatory needs, ICES J. Mar. Sci., 65, 1387-1391, doi:10.1093/icesjms/fsn154, 2008.

Joint, I. and Pomroy, A.: Phytoplankton biomass and production in the southern North Sea, Mar. Ecol. Prog. Ser., 99, 169-182, 1993.

Justić, D., Turner, R. E., and Rabalais, N. N.: Climatic influences on riverine nitrate flux: Implications for coastal marine eutrophication and hypoxia, Estuaries, 26, 1-11, 2003.

Karstensen, J., Stramma, L., and Visbeck, M.: Oxygen minimum zones in the eastern tropical Atlantic and Pacific oceans, Prog. Oceanogr., 77, 331-350, 2008.

Kemp, W. M., Testa, J. M., Conley, D. J., Gilbert, D., and Hagy, J. D.: Temporal responses of coastal hypoxia to nutrient loading and physical controls, Biogeosciences, 6, 2985-3008, 2009, http://www.biogeosciences.net/6/2985/2009/.

Lee, J., South, A. B., and Jennings, S.: Developing reliable, repeatable and accessible methods to provide high resolution estimates of fishing effort distributions from Vessel Monitoring System (VMS) data, ICES J. Mar. Sci., doi:10.1093/icesjms/fsq010, in press, 2010.

Lenhart, H. J., Mills, D. K., Baretta-Bekker, H., van Leeuwen, S. M., der Molen, J. v., Baretta, J. W., Blaas, M., Desmit, X., Kühn, W., Lacroix, G., Los, H. J., Ménesguen, A., Neves, R., Proctor, R., Ruardij, P., Skogen, M. D., Vanhoutte-Brunier, A., Villars, M. T., and Wakelin, S. L.: Predicting the consequences of nutrient reduction on the eutrophication status of the North Sea, J. Mar. Syst., 81, 148-170, doi:10.1016/j.jmarsys.2009.12.014, 2010.

Levin, L. A., Ekau, W., Gooday, A. J., Jorissen, F., Middelburg, J. J., Naqvi, S. W. A., Neira, C., Rabalais, N. N., and Zhang, J.: Effects of natural and human-induced hypoxia on coastal benthos, Biogeosciences, 6, 2063-2098, 2009, http://www.biogeosciences.net/6/2063/2009/.

Long, W. C., Brylawski, B. J., and Seitz, R. D.: Behavioral effects of low dissolved oxygen on the bivalve Macoma balthica, J. Exp. Mar. Biol. Ecol., 359, 34-39, doi:10.1016/j.jembe.2008.02.013, 2008.

Los, F. J., Villars, M. T., and Van der Tol, M. W. M.: A 3-dimensional primary production model (BLOOM/GEM) and its applications to the (southern) North Sea (coupled physical-chemical-ecological model), J. Mar. Syst., 74, 259-294, doi:10.1016/j.jmarsys.2008.01.002, 2008.

Lowe, J. A., Howard, T. P., Pardaens, A., Tinker, J., Holt, J., Wakelin, S., Milne, G., Leake, J., Wolf, J., Horsburgh, K., Reeder, T., Jenkins, G., Ridley, J., Dye, S., and Bradley, S.: UK Climate Projections science report: Marine and coastal projections, Met Office Hadley Centre, Exeter, UK, 99, 2009.

Manov, D. V., Chang, G. C., and Dickey, T. D.: Methods for reducing biofouling of moored optical sensors, J. Atmos. Ocean. Tech., 21, 958-968, doi:10.1175/15200426(2004)021<0958:MFRBOM>2.0.CO;2, 2004.

Mee, L. D.: The Black Sea in crisis: a need for concerted international action, Ambio, 21, 278-286, 1992.

Met Office: online available at: http://www.metoffice.gov.uk/ corporate/pressoffice/2007/pr20071109.html, (last access: 22 
December 2010), 2007.

Middelburg, J. J. and Levin, L. A.: Coastal hypoxia and sediment biogeochemistry, Biogeosciences, 6, 1273-1293, 2009, http://www.biogeosciences.net/6/1273/2009/.

Mills, D. K., Rees, J. M., Rutgers van der Loeff, M., and Laane, R. W. P. M.: Continuous measurement of suspended matter, Sea Technol., 43, 50-54, 2002.

Mills, D. K., Laane, R. W. P. M., Rees, J. M., Rutgers, M., Loeff, v. d., Suylen, J. M., Pearce, D. J., Sivyer, D. B., Heins, C., Platt, K., and Rawlinson, M.: Smartbuoy: A marine environmental monitoring buoy with a difference., in: Elsevier Oceanography Series, Third International Conference on EuroGOOS, Athens, Greece, 311-316, 2003.

OSPAR: Common procedure for the identification of the eutrophication status of the OSPAR maritime area, OSPAR Commission 2005-3, 36, 2005.

Painting, S. J., Devlin, M. J., Rogers, S. I., Mills, D. K., Parker, E. R., and Rees, H. L.: Assessing the suitability of OSPAR EcoQOs for eutrophication vs ICES criteria for England and Wales, Mar. Pollut. Bull., 50, 1569-1584, doi:10.1016/j.marpolbul.2005.06.042, 2005.

Pedersen, F. B.: The Oceanographic and Biological Tidal Cycle Succession in Shallow Sea Fronts in the North Sea and the English Channel, Estuar. Coast. Shelf Sci., 38, 249-269, doi:10.1006/ecss.1994.1017, 1994.

Peeters, J. C. H., Los, F. J., Jansen, R., Haas, H. A., Peperzak, L., and de Vries, I.: The oxygen dynamics of the Oyster Ground, North Sea. Impact of eutrophication and environmental conditions., Ophelia, 42, 257-288, 1995.

Pingree, R. D., Holligan, P. M., and Mardell, G. T.: The effects of vertical stability on phytoplankton distributions in the summer on the northwest European Shelf, Deep-Sea Res., 25, 1011-1028, 1978.

Postma, H. and Rommets, J. W.: Variations of particulate organic carbon in the central North Sea, Neth. J. Sea Res., 18, 31-50, 1984.

Rabalais, N. N., Díaz, R. J., Levin, L. A., Turner, R. E., Gilbert, D., and Zhang, J.: Dynamics and distribution of natural and humancaused hypoxia, Biogeosciences, 7, 585-619, 2010, http://www.biogeosciences.net/7/585/2010/.

Reid, P. C., Lancelot, C., Gieskes, W. W. C., Hagmeier, E., and Weichart, G.: Phytoplankton of the North Sea and its dynamics: A review, Neth. J. Sea Res., 26, 295-331, 1990.

Richardson, K., Visser, A. W., and Pedersen, F. B.: Subsurface phytoplankton blooms fuel pelagic production in the North Sea, J. Plankton Res., 22, 1663-1671, 2000.

Rijnsdorp, A. D., Buys, A. M., Storbeck, F., and Visser, E. G.: Micro-scale distribution of beam trawl effort in the southern North Sea between 1993 and 1996 in relation to the trawling frequency of the sea bed and the impact on benthic organisms, ICES J. Mar. Sci., 55, 403-419, 1998.

Sharples, J., Tweddle, J. F., Green, J. A. M., Palmer, M. R., Kim, Y. N., Hickman, A. E., Holligan, P. M., Moore, C. M., Rippeth, T. P., Simpson, J. H., and Krivtsov, V.: Spring-neap modulation of internal tide mixing and vertical nitrate fluxes at a shelf edge in summer, Limnol. Oceanogr., 52, 1735-1747, 2007.
Skjæraasen, J. E., Nilsen, T., Meager, J. J., Herbert, N. A., Moberg, O., Tronci, V., Johansen, T., and Salvanes, A. G. V.: Hypoxic avoidance behaviour in cod (Gadus morhua L.): The effect of temperature and haemoglobin genotype, J. Exp. Mar. Biol. Ecol., 358, 70-77, doi:10.1016/j.jembe.2008.01.010, 2008.

Stramma, L., Johnson, G. C., Sprintall, J., and Mohrholz, V.: Expanding oxygen-minimum zones in the tropical oceans, Science, 320, 655-658, doi:10.1126/science.1153847, 2008.

Tett, P. B.: Plankton, in: Biological surveys of estuaries and coasts, edited by: Baker, J. M. and Wolff, J. W., Cambridge University Press, Cambridge, 280-341, 1987.

Tett, P., Gowen, R., Mills, D., Fernandes, T., Gilpin, L., Huxham, M., Kennington, K., Read, P., Service, M., Wilkinson, M., and Malcolm, S.: Defining and detecting undesirable disturbance in the context of marine eutrophication, Mar. Pollut. Bull., 55, 282 297, 2007.

Trimmer, M., Petersen, J., Sivyer, D. B., Mills, C., Young, E., and Parker, E. R.: Impact of long-term benthic trawl disturbance on sediment sorting and biogeochemistry in the southern North Sea, Mar. Ecol. Prog. Ser., 298, 79-94, 2005.

Tunnicliffe, V.: High species diversity and abundance of the epibenthic community in an oxygen-deficient basin, Nature, 294, 354356, 1981.

Van Raaphorst, W., Malschaert, H., and Van Haren, H.: Tidal resuspension and deposition of particulate matter in the Oyster Grounds, North Sea, J. Mar. Res., 56, 257-291, 1998.

Vaquer-Sunyer, R. and Duarte, C. M.: Thresholds of hypoxia for marine biodiversity, P. Natl. Acad. Sci. USA, 105, 15452-15457, doi:10.1073/pnas.0803833105, 2008.

Wang, S., Yuen, S. S. F., Randall, D. J., Hung, C. Y., Tsui, T. K. N., Poon, W. L., Lai, J. C. C., Zhang, Y., and Lin, H.: Hypoxia inhibits fish spawning via LH-dependent final oocyte maturation, Comp. Biochem. Phys. C, 148, 363-369, doi:10.1016/j.cbpc.2008.03.014, 2008.

Weston, K., Jickells, T. D., Fernand, L., and Parker, E. R.: Nitrogen cycling in the southern North Sea: Consequences for total nitrogen transport, Estuar. Coast. Shelf Sci., 59, 559-573, doi:10.1016/j.ecss.2003.11.002, 2004.

Weston, K., Fernand, L., Mills, D. K., Delahunty, R., and Brown, J.: Primary production in the deep chlorophyll maximum of the central North Sea, J. Plankton Res., 27, 909-922, doi:10.1093/plankt/fbi064, 2005.

Weston, K., Fernand, L., Nicholls, J., Marca-Bell, A., Mills, D., Sivyer, D., and Trimmer, M.: Sedimentary and water column processes in the Oyster Grounds: A potentially hypoxic region of the North Sea, Mar. Environ. Res., 65, 235-249, doi:10.1016/j.marenvres.2007.11.002, 2008.

Williams, P. J. le B. and Jenkinson, N.: A transportable microprocessor-controlled precise Winkler titration suitable for field station and shipboard use, Limnol. Oceanogr., 27, 576-584, 1982.

Winkler, L. W.: Die Bestimmung des in wasser gelosten Sauerstoffes, Ber. Dtsch. Chem. Ges., 21, 2843-2855, 1888. 